\title{
Pancreatic Cancer and Its Microenvironment-Recent Advances and Current Controversies
}

\author{
Kinga B. Stopa ${ }^{1,+} \oplus$, Agnieszka A. Kusiak ${ }^{2, \dagger}$, Mateusz D. Szopa ${ }^{2}$, Pawel E. Ferdek ${ }^{2, *}$ and \\ Monika A. Jakubowska ${ }^{1, *}$ \\ 1 Malopolska Centre of Biotechnology, Jagiellonian University, ul. Gronostajowa 7A, 30-387 Krakow, Poland; \\ kinga.stopa@doctoral.uj.edu.pl \\ 2 Faculty of Biochemistry, Biophysics and Biotechnology, Jagiellonian University, ul. Gronostajowa 7, \\ 30-387 Krakow, Poland; a.kusiak@student.uj.edu.pl (A.A.K.); mateusz.szopa@student.uj.edu.pl (M.D.S.) \\ * Correspondence: pawel.ferdek@uj.edu.pl (P.E.F.); monika.jakubowska@uj.edu.pl (M.A.J.) \\ + These authors contributed equally to this work.
}

Received: 9 April 2020; Accepted: 29 April 2020; Published: 1 May 2020

\begin{abstract}
Pancreatic ductal adenocarcinoma (PDAC) causes annually well over 400,000 deaths world-wide and remains one of the major unresolved health problems. This exocrine pancreatic cancer originates from the mutated epithelial cells: acinar and ductal cells. However, the epithelia-derived cancer component forms only a relatively small fraction of the tumor mass. The majority of the tumor consists of acellular fibrous stroma and diverse populations of the non-neoplastic cancer-associated cells. Importantly, the tumor microenvironment is maintained by dynamic cell-cell and cell-matrix interactions. In this article, we aim to review the most common drivers of PDAC. Then we summarize the current knowledge on PDAC microenvironment, particularly in relation to pancreatic cancer therapy. The focus is placed on the acellular stroma as well as cell populations that inhabit the matrix. We also describe the altered metabolism of PDAC and characterize cellular signaling in this cancer.
\end{abstract}

Keywords: CAFs; microenvironment; pancreatic cancer; PDAC; signaling; stroma

\section{Introduction}

Approximately $95 \%$ of the pancreas is composed of the highly specialized epithelial cells [1]. Secretory epithelia, pancreatic acinar cells (PACs) and pancreatic duct cells (PDCs), are characterized by highly specialized functions, reflected by their sophisticated cell architecture and structural polarity [2]: apico-basal for the acinar cells [3] and planar for the duct cells [4]. It is now commonly accepted that in the normal epithelial tissues, the maintenance of cell polarity is fundamental for preservation of tissue integrity and functions [5]. However, in the process of malignant tissue transformation, this physio-functional propensity of the epithelia becomes severely disrupted [5].

Physiologically, pancreatic secretory epithelia play unique roles in the digestion. The main role of PACs is production, storage (as zymogen granules) and release of digestive enzymes [6], whereas PDCs secrete water and electrolyte $\left(\mathrm{HCO}_{3}{ }^{-}\right)$, which, together with the enzymes, formulate alkaline pancreatic juice [7].

Although seemingly 'terminally' differentiated, PACs and PDCs have the ability to reversibly assume the phenotype characteristic of other cells. For instance, in response to the injury, acinar cells may become transdifferentiated into duct-like cells and develop acinar-to-ductal metaplasia (ADM); and vice versa: ductal-to-acinar (DAM). In each case, one predominant cell type becomes replaced by another [8-10]. ADM is characterized by remarkable cell plasticity, often apparent under cellular stress (e.g., recurrent inflammation), whereby the presence of oncogene KRAS may further cell transformation into benign stages called pancreatic intraepithelial neoplasia (PanINs) [9-12]. By contrast, withdrawal 
of the stressor may favor a reversion toward the primary acinar phenotype $[9,13]$. However, as a result of the secondary genetic aberrations (e.g., inactivation of tumor-suppressor genes), PanINs may undergo a malignant transformation, which leads to the development of pancreatic ductal adenocarcinoma (PDAC) [9].

Importantly, even at early PanIN stages, pancreatic epithelia may transdifferentiate toward the mesenchymal fate in the program(s) called epithelial-mesenchymal transition (EMT) [14]. This transition causes marked changes of the phenotype: not only manifested as the loss of polarity, but also as disruption of the contact-mediated (cell-cell and cell-matrix) signaling $[5,9,14]$. What is more, a neoplastic cell increases its potential for migration and may leave the original niche and enter the bloodstream. In circulation, the mesenchymal phenotype is maintained until the cell has reached a new habitable niche [14]. If the cell was malignantly transformed, this process can initiate metastasis formation [14]. However, it remains controversial whether or not the presence of pancreatic epithelial cells in circulation would deliver any relevant diagnostic/prognostic data for the patients [14-16].

The abundance and complexity of the precursor stages, the ease to disseminate into distant metastatic niches and the ability to undergo EMT, all make PDAC particularly difficult to cure. The statistical data of the American Cancer Society website: cancer.org, convey a tragic message that the 5-year relative survival rate post diagnosis, combined for all SEER stages (Surveillance, Epidemiology, and End Results), is about 9\%. In this review article, we aim to summarize the mutations that initiate PDAC development. We then focus on the specific PDAC microenvironment formed by the acellular matrix and populations of tumor-associated cells. Finally, we characterize the role of hypoxia, altered cancer metabolism and microbial flora, as well as fat and calcium signaling pathways in the pancreatic carcinogenesis.

\section{Driver Mutations in PDAC}

Pancreatic carcinogenesis is largely driven by mutations in certain oncogenes and tumor suppressor genes. This includes activation of the KRAS oncogene as well as inactivation of CDKN2A tumor suppressor gene, followed by a loss of function of $p 53$ and SMAD4 [17]. Other less frequent contributors are mutations in DPC4, PTEN, Myc and BRCA2 genes [18,19]. In 2008 the pioneering work by Jones et al. applied microarrays containing probes for $\sim 1$ million single-nucleotide polymorphisms to identify somatic mutations in 24 pancreatic cancer samples [20]. This study described well over 1500 somatic mutations, majority of which were missense $(62.4 \%)$ and synonymous (25.5\%) mutations [20].

\subsection{Activation of Oncogenes-KRAS}

In human cancers, KRAS mutation is considered to be one of the most common driver mutation in the lung, colorectal and pancreatic carcinogeneses [21]. Activation of the KRAS oncogene occurs early in the course of PDAC progression and it can account for up to $30 \%$ of the non-invasive ductal lesions, increasing to almost $95 \%$ in aggressive PDAC [22,23].

KRAS is an intracellular membrane-bound protein that belongs to the small GTPase superfamily, involved in regulation of the cell cycle, cell proliferation, differentiation, metabolism and apoptosis [24,25]. KRAS can exist in two different states: the inactive GDP-bound and the active GTP-bound, which enables it to act as a molecular switch [23]. As a consequence of the point mutations in codon 12 (also 13 or 61) resulting in amino acid substitution (e.g., KRAS ${ }^{\mathrm{G} 12 \mathrm{D}}, \mathrm{KRAS}^{\mathrm{G} 12 \mathrm{C}}$ [26]), KRAS becomes resistant to inactivation by GTPase activating proteins (GAPs) [19]. This in turn leads to the constitutive KRAS activity and a subsequent overstimulation of cell proliferation and pro-survival signaling, including PI3K and RAF/MAP/MEK pathways [17]. Activated KRAS is also involved in a number of signaling cascades that regulate cell metabolism, reprogramming, as well as inflammation and angiogenesis [25]. What makes the matters worse is that these genetic alterations occur not only in cancer cells, but may also be present in the tumor microenvironment, for example in pancreatic stellate cells (PSCs) [27].

In the scientific community it is commonly perceived that an effective therapy that could selectively target KRAS might become an important step forward in the PDAC treatment. Currently developed 
therapeutic approaches address this concept, and some indirect strategies attempt to affect cellular location of KRAS itself or target its downstream effectors [25,28,29].

One of the first therapeutic approaches proposed to decrease KRAS activity was inhibition of mutated KRAS expression. This was attempted by application of a small interfering RNA (siRNA) called ISI6957 [30]. However, due to the short circulating half-life, inefficient cellular uptake and off-target toxicity (that is toward normal cells), this therapy did not proceed into the clinic [30,31]. Only very recently, peptide-based nanoparticles have been validated as safe and effective carriers of siRNA to the target cells; this strategy was successfully applied to inhibit KRAS expression, which resulted in reduced viability of cancer cells, as tested in vitro and in a KPPC mouse model of PDAC [29].

Another tested therapeutic approach was based on irreversible inhibition of KRAS by a disruption of the conformational changes required for oncoprotein activation. Although conceptually attractive, in practice high intracellular levels of GTP as well as significant affinity of KRAS toward this nucleotide were able to overcome the induced conformational inhibition resulting in the failure of this strategy [25]. Currently, under clinical trials is the first in its class compound AMG 510 that covalently binds to the extra cysteine residue in KRAS ${ }^{\mathrm{G} 12 \mathrm{C}}$ and abolishes the activation of mutated KRAS by locking this protein in its inactive state [32,33].

Recently, increasingly more attention is directed toward post-translational modifications of KRAS, particularly those that inhibit docking of the oncoprotein to the cell membrane and thus affect its intracellular localization. While some of the simplest modifications include prenylation and geranylgeranylation of KRAS, their translation into the clinic is rather unlikely due to the predicted high toxicity [34]. A promising yet unproven approach to target KRAS docking to the plasma membrane could be the application of Deltarasin - an inhibitor of the prenyl-binding chaperon protein PDE $\delta[35,36]$. Since the efficacy of Deltarasin has so far been demonstrated only in the preclinical models, clinical research is still required to test the drug in the human patients $[35,36]$.

Several compounds have been developed to block the pathways downstream of KRAS. Those include RAF and MEK inhibitors disrupting the MAPK signaling pathway. However, studies failed to demonstrate efficacy in PDAC treatment for Selumetinib and Pimasertib, blockers of MEK the MAPK kinase [37,38], or Rigosertib - historically known as a RAS mimetic [39], and recently identified as a microtubule destabilizing agent $[25,40-43]$.

In 2003, a mouse model of PDAC was first used to demonstrate that mutation in KRAS is an initiating event in pancreatic ductal carcinogenesis [18]. In these mice, expression of endogenous KRAS $^{\mathrm{G} 12 \mathrm{D}}$ in progenitor cells was found to be sufficient for the induction of benign lesions, such as PanINs the initial stage of pancreatic carcinogenesis [18,25]. What might be surprising is the fact that there is only $1 \%$ chance that a KRAS mutation-carrying PanIN1 will progress to PDAC [44,45]. However, an effect of mutated KRAS in PDAC could be intensified in the pre-malignant lesions by the presence of the secondary mutations that promote the development of aggressive disease. Indeed, a recent study on transcriptional regulator ATRX (involved in chromatin remodeling) showed that the loss of this protein in female but not male mice increases the susceptibility to pancreatic injury and oncogenic KRAS [45]. These findings point toward the existence of additional (epi)genetic changes that are essential for pancreatic carcinogenesis.

\subsection{Inactivation of Tumor Suppressor Genes}

\subsubsection{CDKN2A}

Loss of function of cyclin-dependent kinase inhibitor 2A (CDKN2A; also known as p16) occurs in more than $85 \%$ of PDAC cases [19,46-49]. The CDKN2A gene is frequently exposed to intragenic mutations, homozygous deletions and promoter hypermethylation, all of which result in a non-functional protein [50]. Frequency of p16 inactivation increases during pancreatic carcinogenesis, and can be identified at its very early stages [51]. Under normal conditions, p16 acts as a regulator of the cell cycle and inhibitor of cyclin-dependent kinases 4 and 6 (CDK4, CDK6) activation. Blockage 
of these kinases disables their interaction with cyclin D1, phosphorylation of retinoblastoma protein $(\mathrm{Rb})$ and halts progression of the G1/S phase cell cycle [50]. Under pathological conditions, loss of functional p16 leads to the unsuppressed cell proliferation, often resulting in PDAC development [52]. Currently ongoing clinical trials (NCT03065062, NCT02501902) test inhibition of CDK4 and CDK6 by Palbociclib, in combination therapies against PDAC.

\subsubsection{TP53}

In 75\% of the PDAC patients, the TP53 suppressor gene is either completely lost or carries missense mutations [53,54]. Mutations in this gene are present in advanced PanIN-3 and invasive cancers, and are often considered to be late events in pancreatic carcinogenesis [51]. TP53 encodes a transcription factor p53, also called The Guardian of the Genome, since it coordinates the whole cell genome function by regulating the cell cycle, metabolism and apoptosis in response to DNA damage $[17,19]$. It is not surprising that in normal cells the level of p53 is under precise control. In these cells, p53 is targeted for proteasomal degradation by E3 ubiquitin-protein ligase MDM2. This post-translational control of p53 level and its activity leads to the rapid response that enables the cell cycle arrest as a result of DNA damage. In cancer, p53 mutant protein interacts with the unchanged p53 protein blocking its normal functions. Despite the above, the effect of TP53 mutations alone on carcinogenesis initiation is rather minor. It is the simultaneous occurrence of mutations in TP53 and KRAS that usually leads to the development of metastatic carcinoma [55].

While not essential for the initiation of pancreatic malignancy, TP53 mutations are responsible for a decreased chemotherapeutic efficiency of PDAC. As a result, various approaches that aim to deprive TP53 or restore its wild-type activity are within scientific and medical interest. One of the emerging therapeutic strategies currently under (pre)clinical evaluations is based on inhibitors of heat shock protein 90 (HSP90). The chaperone activity of HSP90 is important for the transcriptional activity of wild-type p53 [56]; and thus blocking of HSP90 activity could destabilize p53 [57,58]. Also, inhibitors of histone deacetylases (HDAC), e.g., Trichostatin A, which bind directly to the TP53 gene, can reduce expression of this gene and may prove beneficial in PDAC treatment, subject to further validation in the clinic [59].

\subsubsection{SMAD4}

Mutations in SMAD4 have been reported in approximately $60 \%$ of PDAC cases [60]. SMAD4 is a regulator of transcription growth factor-beta (TGF $\beta$ ) signaling pathway that controls cell proliferation, apoptosis, migration and EMT [61]. The loss-of-function mutation in SMAD4 is typical for the advanced stages of PDAC and is correlated with metastasis formation [62]. This makes SMAD4 expression a prognostic factor for the PDAC progression or assessment of the therapy outcome [62].

Importantly, the above-listed mutations do not occur exclusively in cancer cells. It was shown that inactivation of TP53 and PTEN can also be found in the stromal cells where it promotes the progression of different types of cancers [63-65].

\subsection{Non-Coding RNAs}

Apart from the driver mutations, dysregulation of non-coding RNAs (ncRNAs) was shown to influence PDAC initiation and progression. ncRNAs comprise microRNAs (miRNAs), the endogenous single-stranded RNAs (ssRNAs) and long non-coding RNAs (lncRNAs). miRNAs specifically target mRNA for degradation or translation repression; they may also act as decoys for certain proteins $[66,67]$. The role of lncRNAs is more heterogeneous: these ncRNAs can influence the transcription itself as well as post-transcriptional processes and chromatin remodeling [67].

In order to regulate vital cellular processes, e.g., cell growth and differentiation, angiogenesis, migration and apoptosis, miRNAs and lncRNAs are present both in normal and diseased tissues [68,69]. However, in pathology the expression levels of ncRNAs may not change sharply enough to be used as early diagnosis/prognostic markers or the potential targets in anticancer therapies [68,70]. 
miRNAs found in PDAC can be divided into two groups: oncomiRs (miR-21, miR-155 and miR-221) and tsmiRs (miR-146, miR-34 and let-7), based on their oncogenic or tumor suppressing role, respectively [69]. For example, miR-21 expression in PanINs corelates with PDAC aggressiveness, possibly owing to its regulatory role in PI3K signaling, mobilizing CAFs and increasing cancer resistance to therapies $[69,71]$. It was recently shown that downregulation of oncomiR-21 significantly slows down the kinetics of tumor growth in vivo [72]. As for the tsmiRs, downregulated in PDAC tumor suppressor let-7 was demonstrated to modulate cell proliferation and EMT and thus promote pancreatic tumorigenesis [73]. Restoration of let-7b level in combination with GDC-0449 (inhibitor of the Hedgehog signaling) reduced growth of MIA PaCa-2 tumors in nude mouse hosts [74].

Despite the importance of ncRNAs in carcinogenesis, oligonucleotides did not proceed to the clinical trials for PDAC treatment. One of the reasons is a very short in vivo half-life of ncRNAs due to the activity of serum nucleases and renal elimination [75]. However, current preclinical studies aim to target this disadvantageous pharmacokinetics of oligonucleotides in order to increase the efficacy of this therapy, e.g., chemically tailored nanocomplexes have been tested as vehicles for delivery of anti-miRNA oligonucleotides (AMOs). These nanocomplexes demonstrated a remarkable success in trafficking AMOs to the PSCs, wherein they blocked specifically miR-199a and subsequently constrained PSC activation [75].

\section{Microenvironment: Acellular Stroma}

Comprising of $\sim 80 \%$ of the tumor microenvironment (TME), the stroma is an important part of PDAC [76], that functionally can be divided into four subclasses: (i) structural vascularized, (ii) activated, (iii) inflammatory, and (iv) immune [77]. In order to perform its structural and connective roles, the stroma must contain both the acellular matrix formed mainly of water and glycoproteins, and live components non-neoplastic cells. Cellular composition of pancreatic cancer milieu displays a remarkable diversity of cell populations, including fibroblasts, endothelial cells, immune cells (lymphoid and myeloid cells) and even neurons. A predominant fraction of the PDAC stroma are PSCs, that have assumed an active myofibroblast-like phenotype in TME [78]. Dynamic interactions of these cells with other tumor components shape the extracellular matrix (ECM) and influence the neoplasm progression [79].

ECM forms the 'ecosystem' of physical/mechanical cues and makes possible interactions between the structural proteins and other matrix components that are essential for the preservation of tissue integrity. Dynamic structure of ECM is upheld by a constantly changing ratio of matrix metalloproteinases (MMPs) and their inhibitors TIMPs, which is influenced by IL- $1 \alpha$ and TGF $\beta$ signalings [80]. These cellular signaling pathways remodel/reorganize ECM both in cancer and normal tissue, further enhancing it shielding properties [81].

Collagens (COLs) are the major components of ECM. In PDAC, collagens play an intricate role: they reinforce the tumor composition by interacting with $\alpha_{2} \beta_{1}$ integrins that regulate fibril motility and fibril binding to a number of proteins [82]. COL1A influences E-cadherin level and indirectly mediates formation of $\beta$-catenin/E-cadherin complexes that facilitate PDAC progression [83]. Moreover, collagen I promotes the metastatic potential of PDAC by upregulation of N-cadherins by Discoidin domain receptors (DDRs) [84]. PDAC growth can also be affected by the loss of the PTEN gene that encodes phosphatase and tensin homolog (PTEN) protein: this causes higher mobilization of CAFs and eventually a more efficient production of collagen type I $[85,86]$. What is worth noticing is that not only the presence but also the spatial organization of collagen is important for cancer development. As opposed to chronic pancreatitis and the healthy pancreas, collagen fibers in PDAC exhibit a characteristic topology, particularly around malignant ducts, determined by a high alignment and increased length and width [87]. Such a distinctive organization of collagens in the tumor often implies a poor prognosis for patient survival [88].

In research focused on PDAC stroma, polysaccharide hyaluronan (HA) emerges as an extensively studied component of the acellular matrix. Importantly, the abundance of HA in the stroma was 
linked with improved angiogenesis in the tumor parenchyma, as well as increased cell proliferation and migration, all contributing to PDAC development [89]. A dense fibrotic stroma also exerts mechanical stress (compression) on the tumor vessels and thus worsens tissue perfusion, restricts the oxygen/nutrient availability and induces hypoxia. Therefore, various therapeutic strategies have been designed to target HA in pancreatic solid tumors. Among the anti-stromal therapies, administration of hyaluronidase PEGPH20 to PDAC patients showed encouraging outcomes, but only in combination with chemotherapeutics, e.g., Gemcitabine or Nab-paclitaxel [89].

The interplay between cancer cells and the tumor milieu comprises the complex network of signaling cascades. Upregulation of Sonic $(\mathrm{SHH})$, Indian $(\mathrm{IHH})$ and Dessert $(\mathrm{DHH})$ ligands of the Hedgehog signaling pathway is crucial for acinar cell healing after the episode of pancreatitis [90]. However, misregulation of the $S H H$ expression was reported for the (pre)malignant pancreatic lesions PanINs, especially if these ligands were co-expressed with oncogenic KRAS [91]. High levels of SHH ligand contributes to development of desmoplastic reaction in pancreatic cancer, also by the induction of PSC activation [92]. To target the SHH signaling cascade in PDAC, a Hedgehog inhibitor IPI-269609 was tested in vitro and in vivo. Application of IPI-269609 affected the tumor growth; however in a combination therapy with Gemcitabine this inhibitor did not potentiate the effect of the chemotherapeutic [93]. Nevertheless, a newer-class inhibitor IPI-926 improved the delivery of drugs to cancer cells via normalization of the vascular network in the tumor [94].

$\mathrm{Src} / \mathrm{FAK}$ is yet another important signaling cascade characterized by significant changes during tumorigenesis. Src and FAK may become activated by a number of growth factor receptors, mainly epidermal (EGFR), vascular endothelial (VEGFR), fibroblast (FGFR) and plateletderived growth factor receptor (PDGFR); all of the above could activate the Src/FAK pathway [95-97]. In PDAC, Src kinase activity is enhanced, which translates into increased cancer invasion and metastasis formation [98]. Src also becomes upregulated in pancreatitis a disease that substantially increases the risk of PDAC development [99]. Pharmacological inhibition of Src reduced cancer invasiveness and attenuated tumor growth [100,101], whereas blockage of FAK with its inhibitor VS-4718 (clinical trials) decreased the density of the TME and enabled the effective chemo- and immunotherapy [102].

\section{Microenvironment: Cellular Components}

\subsection{Cancer-Associated Fibroblasts}

Cancer-associated fibroblasts (CAFs) are abundant and heterogeneous populations of stromal cells in the microenvironment of pancreatic cancer, that are found both in the tumor itself as well as in its surroundings. CAFs can originate from a variety of cells: (i) activated tissue fibroblasts, (ii) transdifferentiated epithelial cells or pericytes, (iii) mesenchymal progenitor cells recruited into the tumor, and (iv) stem cells [103-106]. It has recently been shown that even pluripotent adipose tissue-derived stromal cells (ASCs) can be recruited from the peripancreatic areas into the tumor [107] and, in response to pro-tumorigenic signals, converted into CAFs [107].

Fibroblasts are spindle-shaped adherent cells involved in ECM protein turnover. They produce and release various cytokines or growth factors as part of the role they play in the regulation of tissue homeostasis. However, fibroblasts can also support tumor growth and cancer progression, promote metastasis formation and modulate tumor response to therapy $[106,108]$. Interestingly, CAFs may assume different phenotypes in distinct cancers/cancer compartments [104,109]. As such, based on their biology and function, CAFs can be divided into five populations: the tumor-promoting ( $p \mathrm{CAF}$ ), tumor-retarding $(r \mathrm{CAF})$, secretory (sCAF), inflammatory (iCAF) and myofibroblast (myoCAF) [106]. Out of the above, myoCAFs and $i$ CAFs are the most common and extensively studied CAF subpopulations in PDAC $[105,110,111]$. These cells are identified by expression of certain markers. For example typical stromal fibroblasts express alpha-smooth muscle actin $(\alpha \mathrm{SMA})$, chondroitin sulfate proteoglycan (NG2), fibroblast-activation protein (FAP) and fibroblasts specific protein-1 (FSP-1), as well as platelet-derived growth factor receptor (PDGFR) [104,105]. While $\alpha$ SMA and FAP are accepted 
to be the most specific markers for myoCAFs, iCAFs are characterized by particularly high expression of proinflammatory interleukin-6 (IL-6) [112].

Under normal conditions, local fibroblasts are quiescent cells with a limited ability to proliferate and migrate. However, a number of signals can promote fibroblast activation and differentiation into myofibroblasts; this includes TGF $\beta$, SHH signaling, changes in the extracellular matrix stiffness, DNA damage, cell-to-cell or cell-to-fiber contact signals, and physiological stress [110]. In PDAC, PSCs are the most likely precursors of CAFs. In the healthy pancreas quiescent PSCs comprise approximately $4-7 \%$ of the organ mass and store vitamin A in cytosolic droplets $[113,114]$. Upon activation, PSCs lose vitamin A and start expressing $\alpha$ SMA [115-117]. However, their transition into $i$ CAFs or myoCAFs depends on TGF $\beta$ and IL-1 signaling [118]. For instance, a very recent study by Somerville et al. has highlighted a role of p63 in the induction of the IL-1 $\alpha$-driven transition of PSCs into iCAFs in the squamous subtype of PDAC [119].

Once transdifferentiated into myofibroblasts, activated PSCs become involved in the production of ECM components, mainly collagens, fibronectin and laminin. This contributes to the tumor desmoplastic reaction one of the main hallmarks of PDAC. Clearly linked to the PSC activity, desmoplastic reaction in PDAC has been recognized as the main factor that worsens the outcome of anti-cancer therapies. In PDAC, dense desmoplasia severely limits vascular perfusion, as well as it decreases the nutrient availability and drug delivery to cancer cells [103]. In addition, CAFs are involved in cancer spread as evidenced by their presence in distant metastases [120].

Our understanding of the CAF influence on carcinogenesis and the efficacy of the therapy has increased over the years owing to the intensified research in the field. While CAFs can act as both the pro- and anti-tumorigenic effectors, their activation (for example - an increase in $\alpha$ SMA expression) and high abundance in the tumor tissue, are usually the indicators of a poor clinical outcome [121-123]. As demonstrated for a metastatic breast cancer, the presence of CAFs circulating in the blood could serve as an additional biomarker of disease severity [124]. Also, a growing body of evidence demonstrates that CAFs contribute toward drug resistance via different mechanisms, including paracrine signaling (e.g., secretion of IL-6, IGF1 or NO, and SDF-1/SATB-1 pathway), or by formation of a dense physical barrier (the stroma) that affects drug delivery to cancer cells [106,108].

Novel therapeutic approaches target mainly those signaling pathways that lead to CAF activation (e.g., TGF $\beta$ signaling), or that aim to restore fibroblast quiescence. Alternative approaches based on complete depletion of CAFs from PDAC unexpectedly resulted in the increased aggressiveness of the tumor [125]. Even selective targeting of the $\alpha \mathrm{SMA}$-positive CAFs in the mouse model of PDAC induced immunosuppression and accelerated progression of the disease [126].

These examples highlight the importance of further studies on the role(s) of CAFs in the development and progression of PDAC. However, the lack of highly-specific CAF markers, a significant heterogeneity of CAF populations and unclear influence of CAFs on the pancreatic carcinogenesis make the future studies particularly challenging [127].

\subsection{Immune Environment in PDAC}

Chemotherapy, often in combination with surgery or radiotherapy, still remains the major therapeutic intervention against pancreatic cancer. However, a growing body of evidence suggests that immunotherapy could improve the outcome of these interventions [128]. While tailoring new therapeutic strategies it pays to remember that solid tumors contain populations of anti- and pro-tumor immune cells that could modulate the outcome of the therapy $[129,130]$. Indeed, in recent years this fact is becoming increasingly more acknowledged in the treatment of solid tumors, including PDAC [131].

\subsubsection{Immune Checkpoint PD-1/PD-L1}

Programmed cell death 1 (PD-1; also known as CD279) is an inhibitory checkpoint molecule that regulates self-tolerance toward different cell types and protects against the immune attack by cytotoxic T cells and pre-B cells [132]. However, when expressed in tumor, this protein prevents the 
immune system from killing neoplastic cells. It is now commonly accepted that blockade of immune checkpoints in certain cancers may be beneficial in cancer therapy [133]. Nevertheless, as evidenced by a recent analysis of the clinical data collected up to November 2018, checkpoint inhibition monotherapy has so far proven ineffective in pancreatic cancer [134].

The presence of local immune response in the tumor is often used as a prognostic factor of the clinical outcome. It was demonstrated that a high number of tumor-infiltrating lymphocytes (TILs) in the stroma provided a reliable indicator for the overall survival (OS) of PDAC patients as well as a predictor for the absence of liver metastases [135]. In one study, 145 pancreatic cancer patients who had undergone pancreatectomy followed by postoperative chemotherapy (mostly Gemcitabine) were tested for TIL number and their distribution in relation to expression of PD-1, its ligand (PD-L1; expressed on macrophages, epithelial and other normal cells), as well as CD8 and FOXP3 in tumor-infiltrating leukocytes [135]. A multivariable analysis demonstrated that PD-1 and CD8, but not PD-L1 and FPXP3, when expressed in TILs, could be associated with better OS as well as local progression- and distant metastases-free survival (LPFS and DMFS, respectively) [135]. This is in line with another study, which suggests that lower PD-L1 expression in the surgically resected tissues, may be a good prognostic factor for the patients independently on the level of TIL [136].

In developing tumors, not only immune cells, but also cancer cells express PD-1. A very recent preclinical study applied RNA-Seq to examine the expression of $P D-1$ gene in the library of hundreds of human cancer cell lines [137]. As a result, pancreatic cancer cell lines $(n=46)$ exhibited higher PD-1 expression than most solid tumor cell lines, even those of other different gastrointestinal cancers [137]. This study also shows that PD-1 expression enhances PDAC growth: PANC-1 cells with stably transfected PD-1 shRNA xenotransplanted into NOD/SCID mouse hosts grown much smaller tumors ( $\sim 67 \%$ lower volume) compared to scrambled shRNA control tumors [137]. The authors of this study also highlighted the importance of PD-1/PD-L1 interaction in activation of mitogen activated-protein kinase (MAPK) signaling and thus regulation of cell proliferation and survival [137].

\subsubsection{Current Strategies to Modulate Immune Checkpoint Blockade (ICB)}

Since attempts to block PD-1/PD-L1 in pancreatic cancer have proven largely disappointing, a number of studies tested combination therapies to target the immune checkpoints in PDAC. To address the problem of poor effectiveness of PD-L1 inhibitors applied as monotherapy, a preclinical study examined the interactome of PD-L1 [138]. This study explored the GEPIA database [139] and found that histone acetyltransferase 1 (HAT-1), a transcriptional regulator of PD-L1, was upregulated in PDAC and associated with the poor prognosis [138]. The authors showed that knocking-down the HAT1 gene decreased PD-L1 and improved the efficacy of immune checkpoint blockade (ICB) [138]. Another preclinical study carried out in the MUC1.Tg mice examined the possibility of immunization of the tumor host with mAb-AR20.5 a tumor antigen-targeting antibody (here: anti-mucin 1, MUC1) [140]. This procedure was then followed by administration of PolyICLC (to induce interferon system in mice [141]) together with anti-PD-L1. This combination resulted in a specific, long-lasting, adaptive response against Panc02.MUC1 tumors. As a result, this study proposed a proof-of-principle strategy of targeting a tumor specific antigen, which, if coupled with agents that act as a vaccine adjuvant and an immune checkpoint inhibitor, could provide an effective and long lasting immunity against PDAC [140]. ICB in a combination with radiotherapy was tested in vitro and in vivo against human and mouse pancreatic cancer models [142]. Radiation not only improved ICB efficacy, but also induced DNA damage, which is a well-known activator of the innate immune response [143]. Radiation-induced signaling pathways, including ATM serine/threonine kinase (ATM) signaling, was modified with a pharmacological ATM inhibitor KU60019 as well as it was blocked genetically [142]. Of note is that the ATM-deficient cancer cells formed larger tumors in the immunosuppressive mouse hosts (NSG; they lack the T, C and NK cells) compared to the syngeneic immunocompetent (FVB/NJ or C57BL/6) hosts [142]. In the latter hosts, the growth of the tumors with genetically silenced expression of the ATM gene (shATM) or the scrambled control (shCon) tumors was monitored in 
response to anti-PD-L1/radiation or combination of those. The approach that combined anti-PD-L1 with radiation either reduced or even abolished the growth of shATM tumors [142]. The authors investigated the mechanisms of down-stream ATM signaling pathway in vivo and showed upregulation in the interferon response. In conclusion, the authors of this study suggested that ATM inhibition induces interferon-mediated innate immunity against PDAC, and by increasing the sensitivity to anti-PD-L1 therapy, may prove beneficial for the therapy outcome if combined with radiotherapy [142]. T-cell checkpoint immunotherapy in PDAC was also investigated in the context of tumor-associated macrophages (TAMs) and their immunosuppressive effect on the therapy outcome [144]. By blocking colony stimulating factor/its receptor CSF1/CSFR1, a depletion of macrophages characterized by a high expression of mannose receptor (CD206) was achieved [144]. Depletion of CD206 ${ }^{\text {high }}$ TAMs and reprogramming of the others, when combined with immune checkpoint blockade with PD-1 or cytotoxic T-lymphocyte-associated protein 4 (CTLA-4) antagonists, improved the anti-tumor immunity [144]. Another study investigated cytokine IL35, an immunosuppressive driver of PDAC growth, in relation to $\mathrm{T}$ cell populations in this tumor. A synergistic effect of IL35 deficiency, achieved by knocking down Ebi3 gene, and anti-PD-1 treatment was reported [145].

\subsubsection{T Cells in Focus}

$\mathrm{T}$ cell populations still remain relatively underexplored in the context of (pre)clinical pancreatic studies. To illustrate this, it was only in 2019 when a previously underappreciated population of unconventional T cells, TCR $\alpha \beta^{+} \mathrm{CD} 4^{-} \mathrm{CD} 8^{-} \mathrm{NK} 1.1^{-}$innate $\alpha \beta$ T-cells (i $\alpha \beta \mathrm{Ts}$ ), was identified to represent as much as $\sim 10 \%$ of T-lymphocytes in PDAC solid tumors (both in mouse and human) [146]. The most current 'trend' in research on T-cells is centered on ex vivo biotechnological engineering of T-cell receptors so that the chimeric artificial receptors (CARs) are expressed on T-cell surface [147]. A novel cell class, the CAR-Ts, carry the genetically redirected receptors that combine antigen-binding and T-cell activating functions in a single receptor [147]. Originally proposed to treat blood malignancies (leukemias and lymphomas [147,148]), CAR-Ts were repurposed as agents against the solid tumors $[148,149]$. However, solid tumors are often very poorly-perfused and have a dense, fibrotic and highly immunosuppressive microenvironment, which makes the application of CAR-Ts technically challenging. Advances on CAR-T in PDAC treatment were review in recent articles [148-150].

\section{Microenvironment: Stress and Stress-Induced Signaling}

\subsection{Hypoxia}

A decreased level of oxygen supply to the tissue results in the development of hypoxia. This condition is characterized by a reduced oxygen level, inadequate to the local body needs. Interestingly, hypoxia is a hallmark of the solid tumors, including PDAC [151]. The first study to assess the extent of hypoxia in pancreatic carcinomas was published 20 years ago [152]. In this clinical investigation a group of seven patients gave their consent to have tumor oxygenation measured intraoperatively using a polarographic electrode [152]). The study revealed a marked difference in the oxygen partial pressure $\left(\mathrm{pO}_{2}\right)$ measured within the tumor and the adjacent normal pancreatic tissues [152]. In this study, the pancreatic neoplasias were shown to be highly hypoxic, of median $\mathrm{pO}_{2}$ as low as $0.0-5.3 \mathrm{mmHg}\left(1 \mathrm{mmHg}=0.13 \% \mathrm{O}_{2}, 133.3 \mathrm{~Pa}\right.$ [153]). Only $6 \%$ of the tumor tissue was characterized by the median $\mathrm{pO}_{2}$ higher than $2.5 \mathrm{mmHg}$ [152]; whereas in the normal pancreatic tissues surrounding the tumor, the median $\mathrm{pO}_{2}$ were much higher and reaching $24.3-92.7 \mathrm{mmHg}$.

Development of a hypoxic fraction in PDAC is influenced by a number of factors, for example a very rapid tumor growth may result in impaired architecture of the tumor vasculature. This largely affects $\mathrm{O}_{2}$ delivery to the tissue [154]. What is more, tumor microenvironment may decrease angiogenesis via the autocrine activity of PSCs, such as secretion of endostatin [154,155]. Also, the physical characteristics of TME, such as its very high density, exerts physical pressure that not only causes hypovascularization in the tumor, but also further limits the blood flow in the dysfunctional tumor 
vessels [155]. These reactions drive a vicious cycle that links desmoplasia with hypoxia. Hypoxia also increases expression of proteins involved in drug efflux and induces cancer cells stemness $[151,156]$.

In order to survive in the limiting microenvironment they inhabit, cancer cells evolved a number of strategies to protect themselves despite the stress conditions. Hypoxia may throw cell homeostasis off balance and thus limit their capabilities to survive. Hypoxia-inducible factors (HIFs) are transcription factors that allow the maintenance of homeostasis under the low availability of $\mathrm{O}_{2}$ [157]. Stability of HIFs is controlled via post-translational modifications, such as hydroxylation and ubiquitination [151]. Constant hydroxylation of a HIF1 $\alpha$ subunit makes HIF1 unstable under normoxic conditions. However, HIF1 becomes stabilized in hypoxia and translocates to the nucleus, where its subunits form heterodimers and bind to the hypoxia response elements (HREs). This regulates transcription of genes that encode proteins involved in angiogenesis (vascular endothelial growth factor VEGF, and its receptors; platelet-derived growth factor B - PDGF-B; heme oxygenase-1 HO-1), metabolism (glucose transporters - GLUT1 and GLUT3, phosphoglycerate kinase 1 - PGK1), proliferation (cyclin D1; TGF $\beta$ ) and invasion (stromal-derived factor 1 - SDF-1; E-cadherin) [158,159].

By exploiting their ability to switch from oxidative phosphorylation to glycolysis, HIFs promote cancer cell survival under hypoxic conditions [157]. Moreover, hypoxia-stabilized HIFs can contribute to EMT of the pancreatic epithelia into malignant neoplastic cells characterized by a high metastatic potential [160]. Reduced $\mathrm{O}_{2}$ levels also facilitate stromal remodeling, further supporting cancer invasion [160]. Finally, hypoxia signaling modifies the interactions between cancer cells and non-neoplastic cells in PDAC: CAFs, PSCs and macrophages, and other cells [160]. What is more, by increasing the expression of granulocyte-macrophage colony-stimulating factor (GM-CSF), HIF1 $\alpha$ promotes Schwann cell migration, perineural invasion and hypersensitivity to pain-inducing stimuli in the PDAC patients [161]. Not surprisingly, expression of HIF1 $\alpha$ is also associated with a bigger tumor size, worse prognosis and increased PDAC invasiveness and metastatic potential [160,162-164]. Several studies confirmed that HIF expression levels can be used as a predictor of the therapy outcome [157]. A growing body of research reveals a correlation between the extent of the hypoxic regions within the tumor and a decreased efficacy of the therapy, particularly radiotherapy [152]. Therefore, assessment of the hypoxic fraction in pancreatic solid tumor prior to the treatment could markedly improve the therapy outcome. Radiotracer fluoromisonidazole $\left[{ }^{18} \mathrm{~F}\right]$ FMISO was shown to be effective in hypoxia imaging in PDAC: its tumor to background ratio was 2.0, and it allowed for 120-150 min imaging time [154].

The main hypoxia response regulators HIFs are the potential targets for anticancer therapies, either per se or in an adjuvant fashion. Various approaches to target HIF1 $\alpha$ have already been undertaken. EZN-2968, an antisense oligonucleotide against HIF1 $\alpha$ mRNA was tested in a pilot clinical trial [165]. However, despite a decreased level of HIF1 $\alpha$ protein, expression of its target genes was not significantly reduced [165]. Minnelide, a drug used to inhibit the transcriptional activity of HIF1 $\alpha$ and decrease the level of pancreatic cancer cell stemness [166], has been evaluated against PDAC in phase II clinical trials [167]. The inhibition of downstream HIF effectors, e.g., HO-1, is another plausible therapeutic strategy to target hypoxia. A very recent study revealed that HO-1 knockdown in human PDAC cell lines resulted in a significant inhibition of cell proliferation under hypoxic conditions [162]. Moreover, as studied in PDAC xenograft tumors grown in a mouse host, HO- 1 inhibition combined with Gemcitabine treatment markedly increased the efficacy of this chemotherapeutic [162].

For improving therapy effectiveness, also blockade of signals that lead to HIF upregulation could prove beneficial [157]. In principle, inhibition of the mTOR signaling pathway that controls HIF1 $\alpha$ translation could be a promising therapeutic approach for cancer therapy. Disappointingly, no significant clinical activity was demonstrated using the mTOR inhibitor Everolimus as a monotherapy to treat Gemcitabine-refractory metastatic pancreatic cancer [168]. However, after several years of unsuccessful attempts, Everolimus again was proposed for clinical tests in combination with other anticancer drugs [169]. 
A relatively novel group of compounds called hypoxia activated prodrugs (HAPs) were designed to specifically target hypoxic environment and thereby improve anticancer effectiveness. The HAPs, often derived from 2-nitroimidazoles, comprise cytostatic and cytotoxic compounds [170]. Under hypoxic conditions, HAPs undergo redox reactions in which they yield chemical agents that decrease cell proliferation or cause cancer cell death. Probably the most recognizable prodrug of this class, TH-302 (also known as Evofosfamide), was used unsuccessfully in a number of clinical trials on different types of cancer, including PDAC [171]. However, one clinical trial (NCT03098160) on immunotherapy combining Ipilimumab and Evofosfamide to target metastatic pancreatic cancer, is still active, but its efficacy is yet to be assessed.

\subsection{Microbiome}

Intricate relation between the microbiome and carcinogenesis is gaining a lot of interest in the field of cancer-related research. Analysis of microflora revealed particular microbe species that inhabit patient-derived PDAC solid tumors, as well as the relation of these species to gut microbiome. Gammaproteobacteria are the most abundant bacteria class that colonizes the tumors $[172,173]$. Interestingly, this particular microbe expresses bacterial enzyme cytidine deaminase (CDDL) that can convert a chemotherapeutic Gemcitabine into its inactive form, $2^{\prime}, 2^{\prime}$-difluorodeoxyuridine [172]. Hence, microbiome may have a direct impact on PDAC chemoresistance. In a mouse model of pancreatic cancer, deprivation of bacteria via oral antibiotic administration was shown to induce remodeling of TME, shifting it from an immunosuppressive state, promoting T-cell activation and differentiation of macrophages in the tumor. This antibacterial treatment also enhanced PD-1 expression, further improving tumor sensitivity to immunotherapy [174]. Although in colon and gastric cancers pathogenic oncogenesis is a direct pathway for disease development, in pancreatic cancer bacterial influence seems of rather indirect nature. As such, it is in conjunction with the oncogenic KRAS when the presence of pathogens throws the Th1/Th2/Th17 cell ratio off balance and accelerates cancer progression [175].

Another plausible pathway of the microbiome-PDAC crosstalk depends on the pancreatic cancer risk factors, such as pancreatitis or diabetes. These often severe conditions cause microbial dysbiosis and increase the gut permeability, further promoting translocation of gut microbes to the pancreas. As a result, Toll-like receptors (TLRs) become activated in the pancreatic parenchyma by the bacterial ligands, what expedites cancer growth [176]. However, consensus on pro- or anti-tumorigenic influence of microbiome has not yet been reached. For example, in contrast to the aforementioned reports some recent studies indicate that high alpha diversity (a parameter that takes into account species richness, evenness/domination) of the microflora is tightly correlated with a good OS in PDAC patients, whereas a low level of alpha diversity may serve as a prognostic marker for a poorer disease outcome. Based on these data, in the early-stages of PDAC progression, composition of patient oral and gut microbiome could be a prognostic factor for estimating the survival success rate [176,177].

Evidence suggests that oral microbial ecosystem, likewise, contribute toward the diversification in prognosis of PDAC patients. Salivary levels of Neisseria elongata and Streptococcus mitis were markedly lowered in patients with pancreatic cancer compared to the control group [178]. On the contrary, Granulicatella adiacens content increased in PDAC cases, which may suggest its correlation with systemic inflammation [178]. Also, the transfer (via contact) of periodontal-associated bacteria Porphyromonas gingivalis and Aggregatibacter actinomycetemcomitans could be related to the higher risk of pancreatic cancer [179]. Hence, changes in oral microbial content may serve as a non-invasive and inexpensive screening tool for the patients.

\subsection{Altered Metabolism}

From the survival standpoint, metabolic adaptability is a crucial feature of cells exposed to the dynamic environmental conditions [180]. Such pressure may pose a challenge even for cancer cells. This is particularly true for pancreatic cancer, since the dense fibrotic stroma in PDAC forms a physical barrier for effective nutrient and oxygen delivery. Therefore, in order to survive, pancreatic cancer 
cells must develop mechanisms altering the typical cell metabolic pathways and thus supply the essential nutrients. Such metabolic rewriting in cancers often implies the prevalence of the anaerobic glycolysis [181] and dependence of cancer on the glycolytic pathway [182]. A phenomenon known as the Warburg effect - more common in cells that exist in the limiting environment, such as cancer cells - is based on a shift from glucose oxidation to other anabolic pathways, such as pentose phosphate pathway (PPP) [183].

Uptake of nutrients exceeding the typical cell needs and increased cell proliferation are facilitated by various oncogenic mutations, including KRAS point mutations and missense TP53. Oncogenic KRAS regulates glucose metabolism through upregulation of the glucose transporter GLUT1 and glucose-transforming enzymes hexokinases (HEK) as well as phosphofructokinase 1 (PFK1) [184]. Oncogenic KRAS also markedly affects the glutamine pathway, which in cancer cells appears to play a pivotal role in nutrient dispensing [185]. Apart from conversion of glutamate to $\alpha$-ketoglutarate using glutamate dehydrogenase 1 (GLUD1), cancer cells utilize glutamic-oxaloacetic transaminase 1 (GOT1) to generate oxaloacetate from glutamine-derived aspartate. Oxaloacetate is then converted into malate and subsequently pyruvate that fuels tricarboxylic acid (TCA) cycle [185]. KRAS mutation, resulting in a decrease of GLUD1 with a simultaneous increase in GOT1, reprograms metabolism in favor of the glutamine pathway. Importantly, the influence of the oncogenic TP53 synergizes with mutated KRAS in cancer metabolic alterations [186]. As illustrated by a recent study, when $\mathrm{p} 53^{\mathrm{R} 270 \mathrm{H}}$ mutation is accompanied by KRAS ${ }^{\mathrm{G} 12 \mathrm{D}}$, they both slow down the branched-chain amino acid (BCAA) metabolism in cancer cells; this may explain the reduction in mitochondrial activity [187]. Another means for targeting TCA in cancer cells is a pharmacological blockade of $\alpha$-ketoglutarate dehydrogenase complex with its inhibitor CPI-613 [187]. This strategy, in combination with FOLFIRINOX, showed promising results in metastatic pancreatic cancer cases [187].

Of note, since aldohexose mannose is similar to glucose, it could interfere with glucose metabolism and modify the levels of the TCA intermediates, important for cancer growth. Mannose supplementation was also tested in combination with cisplatin chemotherapy. Importantly, cisplatin/mannose treatment amplified apoptosis in cancer cells by down-streaming the anti-apoptotic Bcl-2 proteins [188].

Not only glucose and glutamine fuel TCA cycle. Activated PSCs support cancer metabolism through secretion of a non-essential amino acid (NEAA) alanine [189]. This phenomenon is tightly related to autophagy, since it was evidenced that non-autophagic PSCs do not 'feed' cancer cells with NEAAs [189]. The role of autophagy turned out to be critical in regulation of cancer cell proliferation (here: by switching cell metabolism toward anaerobic) and metastasis formation [190]. As such, autophagy repression opens up a therapeutic avenue for pancreatic cancer treatment, also in combination with other approaches [182,190].

Lipid metabolism is a rapidly expanding research area, also in relation to pathophysiology. Since pancreatic cancer cells utilize lipids and fatty acids as a source of energy, it becomes of increasing interest to understand the role these nutrients play in the dysregulated PDAC metabolism [191]. Up-regulation of lipoprotein and cholesterol pathways in PDAC captured scientific attention as potential targets for novel therapeutic strategies. In one study, expression of the low-density lipoprotein receptor (LDLR) was used for cholesterol depletion in a combination therapy, which has proven more effective than Gemcitabine alone [191].

High-fat diet enhances pancreatic cancer progression through elevation in cholecystokinin (CCK) levels [192]. Furthermore, as studied in a KPC mouse model of pancreatic carcinogenesis, high-fat diet resulted in increased size of primary tumors and the higher rate of distant metastasis compared to the control KPC mice fed on a normal-fat diet [193]. In PDAC, pro-tumorigenic effect of lipids on disease progression also relates to the processes of PSC transition into CAFs. Remodeling of PSC lipidome and lipid secretion was shown to support tumor growth by supplying cancer cells with phosphatidylcholines for membrane synthesis, as well as increasing lysophosphatidic acid (LPA) 
production. Since the latter plays a role in wound-healing, it may also support the processes of desmoplastic reaction in PDAC and progression of the disease [194].

\subsection{High Fat Diet, CCK Receptors and PDAC}

Genetic susceptibility to cancer is very well recognized and firmly rooted in the public awareness. Course-book examples include certain mutations in the BRCA1 and BRCA2 genes that significantly increase the risk of developing breast and ovarian cancers [195]. However, environmental factors, such as our diet, also play an important role in carcinogenesis. Substantial evidence has accumulated in recent years and points toward a fatty acid-rich diet as a significant risk factor of pancreatic cancer $[196,197]$. In contrast, low-fat diets are not associated with an increased incidence of the disease [198]; and omega-3 fatty acids may even be able to decrease the risk [199].

Fatty acids are important modulators of CCK secretion by the I-cells of the duodenum [200], a hormone and one of the most important secretagogue for digestive enzymes released by PACs [201]. What is more, it has long been known that CCK at physiological concentrations induces hypertrophy (increase in organ mass) and hyperplasia (increase in cell number) of the pancreas [202,203]. While CCK-A receptor is expressed in the normal mouse pancreas and CCK-B receptor is present in the normal human tissue [204], both CCK-A and CCK-B receptors have been identified on human pancreatic cancer cells as well as in PanINs from mouse and human tissues [205-207]. Since the above indicates that CCK receptors are important for pancreatic cancer development, they might be a viable target for therapeutic intervention. In support of this claim Smith et al. showed that inhibition of both CCK receptors with Proglumide delays the progression of PanINs in mice as well as reduces fibrosis and inflammation in vivo [207]. CCK receptor inhibition was also demonstrated to enhance the response to immunotherapy in pancreatic cancer: simultaneous blockade of CCK receptors and application of immune checkpoint antibody, PD-1 or CTLA-4, significantly decreased the tumor volume, improved survival of the experimental mice and had an effect on the type and number of immune cells found in the tumor microenvironment [208].

In line with the above reports, it has recently been shown that the same CCK receptor antagonist blocks dietary fat-induced growth of pancreatic cancer cells, inhibits metastases in vivo as well as decreases tumor fibrosis; whereas CCK analogue is able to stimulate the growth of Panc02 cells in vitro as long as they possess a functional CCK receptor [192]. Importantly, CCK-KO mice or pancreatic tumors that lack CCK receptors are not affected by dietary fat [192]. Reducing the intake of fat could be an important factor in lowering the risk of pancreatic cancer.

\section{5. $\mathrm{Ca}^{2+}$ Signaling in PDAC}

$\mathrm{Ca}^{2+}$ ions are possibly the most versatile signaling entities that control a wide spectrum of cellular processes, including cell migration, proliferation as well as cell death. Given that these processes are crucial for carcinogenesis, the role of $\mathrm{Ca}^{2+}$ signaling in cancer is widely accepted and has been a subject of numerous reviews in the past $[209,210]$. An increasing number of studies provide evidence for the role of $\mathrm{Ca}^{2+}$ and $\mathrm{Ca}^{2+}$ permeable channels in the development of different cancer types [211,212]. $\mathrm{Ca}^{2+}$ signaling clearly plays a role in the tumor growth as well as affects its invasive and metastatic properties [213]. However, only very recently we have begun to understand the role of $\mathrm{Ca}^{2+}$ channels specifically in pancreatic tumorigenesis.

Store operated $\mathrm{Ca}^{2+}$ entry (SOCE) is the most important $\mathrm{Ca}^{2+}$ influx pathway in non-excitable cells and the major mechanism that replenishes the $\mathrm{ER} \mathrm{Ca}^{2+}$ store [214]. This pathway is triggered in response to a depletion of the intracellular $\mathrm{Ca}^{2+}$ stores and it is mediated by the interaction of two molecules: a plasma membrane channel Orai1 and a $\mathrm{Ca}^{2+}$ sensor stromal interaction molecule 1 (STIM1) located in the ER [215]. Orai1 and STIM1 not only facilitate SOCE in non-transformed cells but also function in different PDAC cell lines playing pro-survival and anti-apoptotic roles [216]. Both STIM1 and Orai1 have previously been shown to play a role in various types of malignancies, such a cervical cancer, breast cancer or prostate cancer [217-219]. Very recently Wang et al. demonstrated 
that STIM1 expression becomes upregulated in human PDAC tissues and the authors suggested that this protein might be a novel predictive and prognostic marker for pancreatic cancer [220]. Expression of STIM1 showed a very similar pattern to HIF1 $\alpha$ both in PDAC cell lines and human samples and it was postulated that the STIM1 promoter activity is regulated under hypoxic conditions by HIF1 $\alpha$ via its binding to HREs on this promoter [220]. What should be taken into consideration is the fact that both Gemcitabine and 5-fluorouracil might be able to upregulate Orai1 and STIM1 even further, increasing SOCE in PDAC and thus making the disease even more resilient to chemotherapy [216]. A very recent report showed that RP4010, a SOCE blocker, inhibited the proliferation of pancreatic cancer cell lines and pancreatic tumor-derived cells; as well as demonstrated that the anti-tumor properties of this pharmacological agent were enhanced in the presence of standard chemotherapy with Gemcitabine or Nab-paclitaxel [221].

Another target, whose importance has been highlighted by recent studies, is P2X7, an ion channel activated by ATP and permeable for $\mathrm{Ca}^{2+}$. Its expression was found in pancreatic cell lines, primary tumor cells as well as mouse PSCs [222,223]. While high concentrations of exogenously applied ATP (as well as P2X7 receptor agonist, BzATP) caused pore formation followed by cell necrosis in PDAC cell lines, inhibition of this receptor with AZ10606120 slowed down cell proliferation [222]. Importantly, this compound also decreased the tumor growth (measured by bioluminescence in vivo) in an orthotopic xenograft mouse model of PDAC, reduced the number of activated PSCs (seen as decreased $\alpha$-SMA expression) as well as inhibited collagen deposition [223]. The authors hypothesize that P2X7 receptor plays a role in PDAC progression and thus its inhibition might ameliorate pancreatic cancer aggressiveness by affecting PDAC proliferation, interaction between cancer cells and PSCs and by reducing the desmoplastic reaction.

\section{Conclusions}

The term 'ecosystem' has been used for decades to address the intricacies of pancreatic solid tumor and acknowledge the complexity of PDAC. Not only it well reflects the abundance of cell types that build the tumor, but also it highlights the dynamics of the cell-cell and cell-matrix interactions.

Although we have accumulated a substantial knowledge about the mechanisms that drive pancreatic carcinogenesis and there have been proposed multiple avenues of therapeutic intervention, PDAC remains a global health problem and a major burden to the financial system. Therefore, not only more research is required to harness the mechanisms that underlie the development of this deadly disease, but also more complex, multidisciplinary treatment approaches are needed.

Better understanding of the biophysical processes present in the acellular component of the stroma may contribute toward the more insightful characteristic of the cells that inhabit tumor microenvironment. In light of recent findings, not only the body's own eukaryotic cells, but also the prokaryotic microbiome, are the vital players in PDAC development and plausible therapeutic targets in PDAC therapy.

Author Contributions: Conceptualization, M.A.J.; writing—original draft preparation, K.B.S., A.A.K., M.A.J., P.E.F. and M.D.S.; writing - review and editing, M.A.J. and P.E.F.; supervision, M.A.J. and P.E.F.; funding acquisition, M.A.J. and P.E.F. All authors have read and accepted the manuscript.

Funding: The authors were supported by the HOMING/2017-3/23 and HOMING/2017-4/31 project grants, both carried out within the HOMING program of the Foundation for Polish Science (Fundacja na rzecz Nauki Polskiej, FNP), co-financed by the European Union under the European Regional Development Fund.

Conflicts of Interest: The authors declare no conflict of interest.

\section{References}

1. Pour, P.M.; Pandey, K.; Batra, S.K. What is the origin of pancreatic adenocarcinoma? Mol. Cancer 2003, 2, 13. [CrossRef] [PubMed]

2. Nelson, W.J. Remodeling Epithelial Cell Organization: Transitions Between Front-Rear and Apical-Basal Polarity. Cold Spring Harb. Perspect. Biol. 2009, 1, a000513. [CrossRef] [PubMed] 
3. Raraty, M.G.T.; Murphy, J.A.; McLoughlin, E.; Smith, D.; Criddle, D.; Sutton, R. Mechanisms of acinar cell injury in acute pancreatitis. Scand. J. Surg. 2005, 94, 89-96. [CrossRef] [PubMed]

4. Flasse, L.; Yennek, S.; Cortijo, C.; Barandiaran, I.S.; Kraus, M.R.-C.; Grapin-Botton, A. Apical restriction of the planar cell polarity component VANGL in pancreatic ducts is required to maintain epithelial integrity. bioRxiv 2019, 2019, 778332.

5. Coradini, D.; Casarsa, C.; Oriana, S. Epithelial cell polarity and tumorigenesis: New perspectives for cancer detection and treatment. Acta Pharmacol. Sin. 2011, 32, 552-564. [CrossRef]

6. Petersen, O.H. Calcium signalling and secretory epithelia. Cell Calcium 2014, 55, 282-289. [CrossRef]

7. Pallagi, P.; Hegyi, P.; Rakonczay, Z. The Physiology and Pathophysiology of Pancreatic Ductal Secretion. Pancreas 2015, 44, 1211-1233. [CrossRef]

8. Means, A.L.; Meszoely, I.M.; Suzuki, K.; Miyamoto, Y.; Rustgi, A.K.; Coffey, R.J.; Wright, C.V.E.; Stoffers, D.A.; Leach, S.D. Pancreatic epithelial plasticity mediated by acinar cell transdifferentiation and generation of nestin-positive intermediates. Development 2005, 132, 3767-3776. [CrossRef]

9. Storz, P. Acinar cell plasticity and development of pancreatic ductal adenocarcinoma. Nat. Rev. Gastroenterol. Hepatol. 2017, 14, 296-304. [CrossRef]

10. Demcollari, T.I.; Cujba, A.-M.; Sancho, R. Phenotypic plasticity in the pancreas: New triggers, new players. Curr. Opin. Cell Biol. 2017, 49, 38-46. [CrossRef]

11. Bailey, J.M.; DelGiorno, K.E.; Crawford, H.C. The secret origins and surprising fates of pancreas tumors. Carcinogenesis 2014, 35, 1436-1440. [CrossRef] [PubMed]

12. Valdez, I.A.; Teo, A.K.K.; Kulkarni, R.N. Cellular stress drives pancreatic plasticity. Sci. Transl. Med. 2015, 7, 273ps2. [CrossRef] [PubMed]

13. Yuan, S.; Norgard, R.J.; Stanger, B.Z. Cellular Plasticity in Cancer. Cancer Discov. 2019, 9, 837-851. [CrossRef] [PubMed]

14. Rhim, A.D.; Mirek, E.T.; Aiello, N.; Maitra, A.; Bailey, J.M.; McAllister, F.; Reichert, M.; Beatty, G.L.; Rustgi, A.K.; Vonderheide, R.H.; et al. EMT and Dissemination Precede Pancreatic Tumor Formation. Cell 2012, 148, 349-361. [CrossRef]

15. Rhim, A.D.; Thege, F.; Santana, S.M.; Lannin, T.B.; Saha, T.N.; Tsai, S.; Maggs, L.R.; Kochman, M.L.; Ginsberg, G.G.; Lieb, J.G.; et al. Detection of circulating pancreas epithelial cells in patients with pancreatic cystic lesions. Gastroenterology 2013, 146, 647-651. [CrossRef]

16. Cauley, C.E.; Pitman, M.B.; Zhou, J.; Perkins, J.; Kuleman, B.; Liss, A.S.; Castillo, C.F.-D.; Warshaw, A.L.; Lillemoe, K.D.; Thayer, S.P. Circulating Epithelial Cells in Patients with Pancreatic Lesions: Clinical and Pathologic Findings. J. Am. Coll. Surg. 2015, 221, 699-707. [CrossRef]

17. Dunne, R.F.; Hezel, A.F. Genetics and Biology of Pancreatic Ductal Adenocarcinoma. Hematol. Clin. N. Am. 2015, 29, 595-608. [CrossRef]

18. Hingorani, S.; Petricoin, E.F.; Maitra, A.; Rajapakse, V.; King, C.; Jacobetz, M.A.; Ross, S.; Conrads, T.P.; Veenstra, T.D.; Hitt, B.A.; et al. Preinvasive and invasive ductal pancreatic cancer and its early detection in the mouse. Cancer Cell 2003, 4, 437-450. [CrossRef]

19. Bazzichetto, C.; Conciatori, F.; Luchini, C.; Simionato, F.; Santoro, R.; Vaccaro, V.; Corbo, V.; Falcone, I.; Ferretti, G.; Cognetti, F.; et al. From Genetic Alterations to Tumor Microenvironment: The Ariadne's String in Pancreatic Cancer. Cells 2020, 9, 309. [CrossRef]

20. Jones, S.; Zhang, X.; Parsons, D.W.; Lin, J.C.-H.; Leary, R.J.; Angenendt, P.; Mankoo, P.; Carter, H.; Kamiyama, H.; Jimeno, A.; et al. Core Signaling Pathways in Human Pancreatic Cancers Revealed by Global Genomic Analyses. Science 2008, 321, 1801-1806. [CrossRef]

21. Waters, A.M.; Der, C.J. KRAS: The Critical Driver and Therapeutic Target for Pancreatic Cancer. Cold Spring Harb. Perspect. Med. 2018, 8, a031435. [CrossRef] [PubMed]

22. Pylayeva-Gupta, Y.; Grabocka, E.; Bar-Sagi, D. RAS oncogenes: Weaving a tumorigenic web. Nat. Rev. Cancer 2011, 11, 761-774. [CrossRef] [PubMed]

23. Eser, S.; Schnieke, A.; Schneider, G.; Saur, D. Oncogenic KRAS signalling in pancreatic cancer. Br. J. Cancer 2014, 111, 817-822. [CrossRef] [PubMed]

24. Partensky, C. Toward a Better Understanding of Pancreatic Ductal Adenocarcinoma. Pancreas 2013, 42, 729-739. [CrossRef] 
25. Jonckheere, N.; Vasseur, R.; Van Seuningen, I. The cornerstone K-RAS mutation in pancreatic adenocarcinoma: From cell signaling network, target genes, biological processes to therapeutic targeting. Crit. Rev. Oncol. 2017, 111, 7-19. [CrossRef]

26. Smit, V.T.; Boot, A.J.; Smits, A.M.; Fleuren, G.J.; Cornelisse, C.J.; Bos, J.L. KRAS codon 12 mutations occur very frequently in pancreatic adenocarcinomas. Nucleic Acids Res. 1988, 16, 7773-7782. [CrossRef]

27. Wang, H.-C.; Lin, Y.-L.; Hsu, C.-C.; Chao, Y.-J.; Hou, Y.-C.; Chiu, T.-J.; Huang, P.-H.; Tang, M.-J.; Chen, L.-T.; Shan, Y.-S. Pancreatic stellate cells activated by mutant KRAS-mediated PAI-1 upregulation foster pancreatic cancer progression via IL-8. Theranostics 2019, 9, 7168-7183. [CrossRef]

28. Downward, J. Targeting RAS signalling pathways in cancer therapy. Nat. Rev. Cancer 2003, 3, 11-22. [CrossRef]

29. Strand, M.S.; Krasnick, B.A.; Pan, H.; Zhang, X.; Bi, Y.; Brooks, C.; Wetzel, C.; Sankpal, N.; Fleming, T.; Goedegebuure, S.P.; et al. Precision delivery of RAS-inhibiting siRNA to KRAS driven cancer via peptide-based nanoparticles. Oncotarget 2019, 10, 4761-4775. [CrossRef]

30. Chen, G.; Oh, S.; Monia, B.P.; Stacey, D.W. Antisense Oligonucleotides Demonstrate a Dominant Role of c-Ki-RAS Proteins in Regulating the Proliferation of Diploid Human Fibroblasts. J. Biol. Chem. 1996, 271, 28259-28265. [CrossRef]

31. Golan, T.; Khvalevsky, E.Z.; Hubert, A.; Gabai, R.M.; Hen, N.; Segal, A.; Domb, A.J.; Harari, G.; Ben-David, E.; Raskin, S.; et al. RNAi therapy targeting KRAS in combination with chemotherapy for locally advanced pancreatic cancer patients. Oncotarget 2015, 6, 24560-24570. [CrossRef]

32. AMG 510 First to Inhibit “Undruggable" KRAS. Cancer Discov. 2019, 9, 988-989. [CrossRef]

33. Canon, J.; Rex, K.; Saiki, A.Y.; Mohr, C.; Cooke, K.; Bagal, D.; Gaida, K.; Holt, T.; Knutson, C.G.; Koppada, N.; et al. The clinical KRAS(G12C) inhibitor AMG 510 drives anti-tumour immunity. Nature 2019, 575, 217-223. [CrossRef] [PubMed]

34. Lobell, R.B.; A Omer, C.; Abrams, M.T.; Bhimnathwala, H.G.; Brucker, M.J.; A Buser, C.; Davide, J.P.; Desolms, S.J.; Bergman, J.M.; Ellis-Hutchings, M.S.; et al. Evaluation of farnesyl:protein transferase and geranylgeranyl:protein transferase inhibitor combinations in preclinical models. Cancer Res. 2001, 61, 8758-8768.

35. Spiegel, J.; Cromm, P.M.; Zimmermann, G.; Grossmann, T.N.; Waldmann, H. Small-molecule modulation of Ras signaling. Nat. Methods 2014, 10, 613-622. [CrossRef]

36. Zimmermann, G.; Papke, B.; Ismail, S.; Vartak, N.; Chandra, A.; Hoffmann, M.; Hahn, S.; Triola, G.; Wittinghofer, A.; Bastiaens, P.I.H.; et al. Small molecule inhibition of the KRAS-PDE $\delta$ interaction impairs oncogenic KRAS signalling. Nature 2013, 497, 638-642. [CrossRef]

37. Von Richter, O.; Massimini, G.; Scheible, H.; Udvaros, I.; Johne, A. Pimasertib, a selective oral MEK1/2 inhibitor: Absolute bioavailability, mass balance, elimination route, and metabolite profile in cancer patients. Br. J. Clin. Pharmacol. 2016, 82, 1498-1508. [CrossRef]

38. Ho, A.L.; Grewal, R.K.; Leboeuf, R.; Sherman, E.J.; Pfister, D.G.; Déandréis, D.; Pentlow, K.S.; Zanzonico, P.B.; Haque, S.; Gavane, S.; et al. Selumetinib-Enhanced Radioiodine Uptake in Advanced Thyroid Cancer. N. Engl. J. Med. 2013, 368, 623-632. [CrossRef]

39. Divakar, S.K.A.; Carpio, R.V.-D.; Dutta, K.; Baker, S.J.; Cosenza, S.C.; Basu, I.; Gupta, Y.K.; Reddy, M.R.; Ueno, L.; Hart, J.R.; et al. A Small Molecule RAS-Mimetic Disrupts RAS Association with Effector Proteins to Block Signaling. Cell 2016, 165, 643-655. [CrossRef]

40. Van Cutsem, E.; Hidalgo, M.; Canon, J.-L.; Macarulla, T.; Bazin, I.; Poddubskaya, E.V.; Manojlović, N.; Radenković, D.; Verslype, C.; Raymond, E.; et al. Phase I/II trial of pimasertib plus gemcitabine in patients with metastatic pancreatic cancer. Int. J. Cancer 2018, 143, 2053-2064. [CrossRef]

41. Bodoky, G.; Timcheva, C.; Spigel, D.R.; La Stella, P.J.; Ciuleanu, T.E.; Pover, G.; Tebbutt, N.C. A phase II open-label randomized study to assess the efficacy and safety of selumetinib (AZD6244 [ARRY-142886]) versus capecitabine in patients with advanced or metastatic pancreatic cancer who have failed first-line gemcitabine therapy. Investig. New Drugs 2011, 30, 1216-1223. [CrossRef] [PubMed]

42. O’Neil, B.H.; Scott, A.J.; Ma, W.W.; Cohen, S.J.; Leichman, L.; Aisner, D.L.; Tejani, M.A.; Cho, J.K.; Granfortuna, J.; Coveler, L.; et al. A phase II/III randomized study to compare the efficacy and safety of rigosertib plus gemcitabine versus gemcitabine alone in patients with previously untreated metastatic pancreatic cancer. Ann. Oncol. 2015, 26, 1923-1929. [CrossRef] [PubMed] 
43. Jost, M.; Chen, Y.; Gilbert, L.A.; Horlbeck, M.A.; Krenning, L.; Menchon, G.; Rai, A.; Cho, M.Y.; Stern, J.J.; Prota, A.E.; et al. Combined CRISPRi/a-Based Chemical Genetic Screens Reveal that Rigosertib Is a Microtubule-Destabilizing Agent. Mol. Cell 2017, 68, 210-223.e6. [CrossRef] [PubMed]

44. Todoric, J.; Antonucci, L.; Di Caro, G.; Li, N.; Wu, X.; Lytle, N.K.; Dhar, D.; Banerjee, S.; Fagman, J.B.; Browne, C.D.; et al. Stress-Activated NRF2-MDM2 Cascade Controls Neoplastic Progression in Pancreas. Cancer Cell 2017, 32, 824-839.e8. [CrossRef]

45. Hruban, R.H.; Maitra, A.; Goggins, M. Update on Pancreatic Intraepithelial Neoplasia. Int. J. Clin. Exp. Pathol. 2008, 1, 306-316.

46. Young, C.C.; Baker, R.M.; Howlett, C.J.; Hryciw, T.; Herman, J.E.; Higgs, D.; Gibbons, R.J.; Crawford, H.; Brown, A.; Pin, C.L. The Loss of ATRX Increases Susceptibility to Pancreatic Injury and Oncogenic KRAS in Female But Not Male Mice. Cell. Mol. Gastroenterol. Hepatol. 2019, 7, 93-113. [CrossRef]

47. Caldas, C.; Hahn, S.; Da Costa, L.T.; Redston, M.S.; Schutte, M.; Seymour, A.B.; Weinstein, C.L.; Hruban, R.H.; Yeo, C.J.; Kern, S.E. Frequent somatic mutations and homozygous deletions of the p16 (MTS1) gene in pancreatic adenocarcinoma. Nat. Genet. 1994, 8, 27-32. [CrossRef]

48. Schutte, M.; Hruban, R.H.; Geradts, J.; Maynard, R.; Hilgers, W.; Rabindran, S.K.; A Moskaluk, C.; A Hahn, S.; Schwarte-Waldhoff, I.; Schmiegel, W.; et al. Abrogation of the Rb/p16 tumor-suppressive pathway in virtually all pancreatic carcinomas. Cancer Res. 1997, 57, 3126-3130.

49. McWilliams, R.; Wieben, E.D.; Rabe, K.G.; Pedersen, K.S.; Wu, Y.; Sicotte, H.; Petersen, G.M. Prevalence of CDKN2A mutations in pancreatic cancer patients: Implications for genetic counseling. Eur. J. Hum. Genet. 2010, 19, 472-478. [CrossRef]

50. Liggett, W.H.; Sidransky, D. Role of the p16 tumor suppressor gene in cancer. J. Clin. Oncol. 1998, 16, 1197-1206. [CrossRef]

51. Maitra, A.; Adsay, N.V.; Argani, P.; Iacobuzio-Donahue, C.; De Marzo, A.; Cameron, J.L.; Yeo, C.J.; Hruban, R.H. Multicomponent Analysis of the Pancreatic Adenocarcinoma Progression Model Using a Pancreatic Intraepithelial Neoplasia Tissue Microarray. Mod. Pathol. 2003, 16, 902-912. [CrossRef] [PubMed]

52. Kim, W.Y.; Sharpless, N.E. The regulation of ink4/arf in cancer and aging. Cell 2006, 127, 265-275. [CrossRef]

53. Rozenblum, E.; Schutte, M.; Goggins, M.; A Hahn, S.; Panzer, S.; Zahurak, M.; Goodman, S.N.; A Sohn, T.; Hruban, R.H.; Yeo, C.J.; et al. Tumor-suppressive pathways in pancreatic carcinoma. Cancer Res. 1997, 57, 1731-1734.

54. Scarpa, A.; Capelli, P.; Mukai, K.; Zamboni, G.; Oda, T.; Iacono, C.; Hirohashi, S. Pancreatic adenocarcinomas frequently show p53 gene mutations. Am. J. Pathol. 1993, 142, 1534-1543. [PubMed]

55. Hingorani, S.; Wang, L.; Multani, A.S.; Combs, C.; Deramaudt, T.B.; Hruban, R.H.; Rustgi, A.K.; Chang, S.; Tuveson, D.A. Trp53R172H and KrasG12D cooperate to promote chromosomal instability and widely metastatic pancreatic ductal adenocarcinoma in mice. Cancer Cell 2005, 7, 469-483. [CrossRef] [PubMed]

56. Walerych, D.; Kudla, G.; Gutkowska, M.; Wawrzynow, B.; Muller, L.; King, F.W.; Helwak, A.; Boros, J.; Zylicz, A.; Żylicz, M. Hsp90 Chaperones Wild-Type p53 Tumor Suppressor Protein. J. Biol. Chem. 2004, 279, 48836-48845. [CrossRef] [PubMed]

57. Trepel, J.; Mollapour, M.; Giaccone, G.; Neckers, L.M. Targeting the dynamic HSP90 complex in cancer. Nat. Rev. Cancer 2010, 10, 537-549. [CrossRef]

58. Zhou, X.; Hao, Q.; Lu, H. Mutant p53 in cancer therapy-the barrier or the path. J. Mol. Cell Biol. 2018, 11, 293-305. [CrossRef]

59. Stojanovic, N.; Hassan, Z.; Wirth, M.; Wenzel, P.; Beyer, M.; Schäfer, C.; Brand, P.; Kroemer, A.; Stauber, R.H.; Schmid, R.M.; et al. HDAC1 and HDAC2 integrate the expression of p53 mutants in pancreatic cancer. Oncogene 2016, 36, 1804-1815. [CrossRef]

60. Iacobuzio-Donahue, C.A.; Fu, B.; Yachida, S.; Luo, M.; Abe, H.; Henderson, C.M.; Vilardell, F.; Wang, Z.; Keller, J.W.; Banerjee, P.; et al. DPC4 Gene Status of the Primary Carcinoma Correlates With Patterns of Failure in Patients With Pancreatic Cancer. J. Clin. Oncol. 2009, 27, 1806-1813. [CrossRef]

61. Massagué, J.; Blain, S.W.; Lo, R.S. TGFbeta signaling in growth control, cancer, and heritable disorders. Cell 2000, 103. [CrossRef]

62. Khan, M.A.; Azim, S.; Zubair, H.; Bhardwaj, A.; Patel, G.K.; Khushman, M.; Singh, A.P.; Singh, A.P. Molecular Drivers of Pancreatic Cancer Pathogenesis: Looking Inward to Move Forward. Int. J. Mol. Sci. 2017, 18, 779. [CrossRef] [PubMed] 
63. Hill, R.; Song, Y.; Cardiff, R.D.; Van Dyke, T. Selective Evolution of Stromal Mesenchyme with p53 Loss in Response to Epithelial Tumorigenesis. Cell 2005, 123, 1001-1011. [CrossRef] [PubMed]

64. Trimboli, A.J.; Cantemir-Stone, C.Z.; Li, F.; Wallace, J.A.; Merchant, A.; Creasap, N.; Thompson, J.C.; Caserta, E.; Wang, H.; Chong, J.-L.; et al. Pten in stromal fibroblasts suppresses mammary epithelial tumours. Nature 2009, 461, 1084-1091. [CrossRef] [PubMed]

65. Kiaris, H.; Trimis, G.; Frangou-Plemmenou, M.; Pafiti-Kondi, A.; Chatzistamou, I.; Kalofoutis, A. Evidence for Nonautonomous Effect of p53 Tumor Suppressor in Carcinogenesis. Cancer Res. 2005, 65, 1627-1630. [CrossRef] [PubMed]

66. Wahid, F.; Shehzad, A.; Khan, T.; Kim, Y.Y. MicroRNAs: Synthesis, mechanism, function, and recent clinical trials. Biochim. Biophys. Acta (BBA) Bioenerg. 2010, 1803, 1231-1243. [CrossRef] [PubMed]

67. Dragomir, M.P.; Kopetz, S.A.; Ajani, J.; Calin, G.A. Non-coding RNAs in GI cancers: From cancer hallmarks to clinical utility. Gut 2020, 69, 748-763. [CrossRef]

68. Gupta, S.C.; Tripathi, Y.N. Potential of long non-coding RNAs in cancer patients: From biomarkers to therapeutic targets. Int. J. Cancer 2016, 140, 1955-1967. [CrossRef]

69. Baradaran, B.; Shahbazi, R.; Khordadmehr, M. Dysregulation of key microRNAs in pancreatic cancer development. Biomed. Pharmacother. 2019, 109, 1008-1015. [CrossRef]

70. Garajová, I.; Le Large, T.Y.; Frampton, A.E.; Rolfo, C.D.; Voortman, J.; Giovannetti, E. Molecular Mechanisms Underlying the Role of MicroRNAs in the Chemoresistance of Pancreatic Cancer. BioMed Res. Int. 2014, 2014, 1-17. [CrossRef]

71. Kadera, B.E.; Li, L.; Toste, P.A.; Wu, N.; Adams, C.; Dawson, D.W.; Donahue, T.R. MicroRNA-21 in pancreatic ductal adenocarcinoma tumor-associated fibroblasts promotes metastasis. PLoS ONE 2013, 8, e71978. [CrossRef] [PubMed]

72. Sicard, F.; Gayral, M.; Lulka, H.; Buscail, L.; Cordelier, P. Targeting miR-21 for the Therapy of Pancreatic Cancer. Mol. Ther. 2013, 21, 986-994. [CrossRef] [PubMed]

73. Torrisani, J.; Bournet, B.; Du Rieu, M.C.; Bouisson, M.; Souque, A.; Escourrou, J.; Buscail, L.; Cordelier, P. let-7 MicroRNA Transfer in Pancreatic Cancer-Derived Cells Inhibits In Vitro Cell Proliferation but Fails to Alter Tumor Progression. Hum. Gene Ther. 2009, 20, 831-844. [CrossRef] [PubMed]

74. Kumar, V.; Mondal, G.; Slavik, P.; Rachagani, S.; Batra, S.K.; Mahato, R.I. Codelivery of Small Molecule Hedgehog Inhibitor and miRNA for Treating Pancreatic Cancer. Mol. Pharm. 2015, 12, 1289-1298. [CrossRef]

75. Schnittert, J.; Kuninty, P.R.; Bystry, T.F.; Brock, R.; Storm, G.; Prakash, J. Anti-microRNA targeting using peptide-based nanocomplexes to inhibit differentiation of human pancreatic stellate cells. Nanomedicine 2017, 12, 1369-1384. [CrossRef]

76. Neesse, A.; Krug, S.; Gress, T.M.; Tuveson, D.A.; Michl, P. Emerging concepts in pancreatic cancer medicine: Targeting the tumor stroma. OncoTargets Ther. 2013, 7, 33-43. [CrossRef]

77. Puleo, F.; Nicolle, R.; Blum, Y.; Cros, J.; Marisa, L.; Demetter, P.; Quertinmont, E.; Svrcek, M.; Elarouci, N.; Iovanna, J.L.; et al. Stratification of Pancreatic Ductal Adenocarcinomas Based on Tumor and Microenvironment Features. Gastroenterology 2018, 155, 1999-2013.e3. [CrossRef]

78. Fu, Y.; Liu, S.; Zeng, S.; Shen, H. The critical roles of activated stellate cells-mediated paracrine signaling, metabolism and onco-immunology in pancreatic ductal adenocarcinoma. Mol. Cancer 2018, 17, 62. [CrossRef]

79. Schnittert, J.; Bansal, R.; Prakash, J. Targeting Pancreatic Stellate Cells in Cancer. Trends Cancer 2019, 5, 128-142. [CrossRef]

80. Tjomsland, V.; Pomianowska, E.; Aasrum, M.; Sandnes, D.; Verbeke, C.S.; Gladhaug, I.P. Profile of MMP and TIMP Expression in Human Pancreatic Stellate Cells: Regulation by IL- $1 \alpha$ and TGF $\beta$ and Implications for Migration of Pancreatic Cancer Cells. Neoplasia 2016, 18, 447-456. [CrossRef]

81. Veenstra, V.; Garcia-Garijo, A.; Van Laarhoven, H.W.; Bijlsma, M.F. Extracellular Influences: Molecular Subclasses and the Microenvironment in Pancreatic Cancer. Cancers 2018, 10, 34. [CrossRef] [PubMed]

82. Shintani, Y.; Hollingsworth, M.A.; Wheelock, M.J.; Johnson, K.R. Collagen I Promotes Metastasis in Pancreatic Cancer by Activating c-Jun NH2-Terminal Kinase 1 and Up-regulating N-Cadherin Expression. Cancer Res. 2006, 66, 11745-11753. [CrossRef] [PubMed]

83. Koenig, A.; Mueller, C.; Hasel, C.; Adler, G.; Menke, A. Collagen Type I Induces Disruption of E-Cadherin-Mediated Cell-Cell Contacts and Promotes Proliferation of Pancreatic Carcinoma Cells. Cancer Res. 2006, 66, 4662-4671. [CrossRef] [PubMed] 
84. Huang, H.; Svoboda, R.A.; Lazenby, A.J.; Saowapa, J.; Chaika, N.; Ding, K.; Wheelock, M.J.; Johnson, K.R. Up-regulation of N-cadherin by Collagen I-activated Discoidin Domain Receptor 1 in Pancreatic Cancer Requires the Adaptor Molecule Shc1. J. Biol. Chem. 2016, 291, 23208-23223. [CrossRef] [PubMed]

85. Álvarez-Garcia, V.; Tawil, Y.; Wise, H.M.; Leslie, N.R. Mechanisms of PTEN loss in cancer: It's all about diversity. Semin. Cancer Biol. 2019, 59, 66-79. [CrossRef] [PubMed]

86. Jolly, L.A.; Novitskiy, S.V.; Owens, P.; Massoll, N.; Cheng, N.; Fang, W.; Moses, H.L.; Franco, A.T. Fibroblast-Mediated Collagen Remodeling Within the Tumor Microenvironment Facilitates Progression of Thyroid Cancers Driven by BrafV600E and Pten Loss. Cancer Res. 2016, 76, 1804-1813. [CrossRef]

87. Drifka, C.R.; Tod, J.; Loeffler, A.G.; Liu, Y.; Thomas, G.J.; Eliceiri, K.W.; Kao, W.J. Periductal stromal collagen topology of pancreatic ductal adenocarcinoma differs from that of normal and chronic pancreatitis. Mod. Pathol. 2015, 28, 1470-1480. [CrossRef]

88. Drifka, C.R.; Loeffler, A.G.; Mathewson, K.; Keikhosravi, A.; Eickhoff, J.C.; Liu, Y.; Weber, S.M.; Kao, W.J.; Eliceiri, K.W. Highly aligned stromal collagen is a negative prognostic factor following pancreatic ductal adenocarcinoma resection. Oncotarget 2016, 7, 76197-76213. [CrossRef]

89. Sato, N.; Kohi, S.; Hirata, K.; Goggins, M. Role of hyaluronan in pancreatic cancer biology and therapy: Once again in the spotlight. Cancer Sci. 2016, 107, 569-575. [CrossRef]

90. Fendrich, V.; Esni, F.; Garay, M.V.R.; Feldmann, G.; Habbe, N.; Dor, Y.; Stoffers, R.; Leach, S.D.; Maitra, A.; Jensen, J.N.; et al. Hedgehog signaling is required for effective regeneration of exocrine pancreas. Gastroenterology 2008, 135, 621-631. [CrossRef]

91. Thayer, S.P.; Di Magliano, M.P.; Heiser, P.W.; Nielsen, C.M.; Roberts, D.J.; Lauwers, G.Y.; Qi, Y.P.; Gysin, S.; Fernández-del Castillo, C.; Yajnik, V.; et al. Hedgehog is an early and late mediator of pancreatic cancer tumorigenesis. Nature 2003, 425, 851-856. [CrossRef] [PubMed]

92. Bailey, J.M.; Swanson, B.J.; Hamada, T.; Eggers, J.P.; Singh, P.K.; Caffery, T.; Ouellette, M.M.; Hollingsworth, M.A. Sonic hedgehog promotes desmoplasia in pancreatic cancer. Clin. Cancer Res. 2008, 14, 5995-6004. [CrossRef] [PubMed]

93. Feldmann, G.; Fendrich, V.; McGovern, K.; Bedja, D.; Bisht, S.; Alvarez, H.; Koorstra, J.-B.M.; Habbe, N.; Karikari, C.; Mullendore, M.; et al. An orally bioavailable small-molecule inhibitor of Hedgehog signaling inhibits tumor initiation and metastasis in pancreatic cancer. Mol. Cancer Ther. 2008, 7, 2725-2735. [CrossRef] [PubMed]

94. Olive, K.P.; Jacobetz, M.A.; Davidson, C.J.; Gopinathan, A.; McIntyre, D.; Honess, D.; Madhu, B.; Goldgraben, M.A.; Caldwell, M.E.; Allard, D.; et al. Inhibition of Hedgehog Signaling Enhances Delivery of Chemotherapy in a Mouse Model of Pancreatic Cancer. Science 2009, 324, 1457-1461. [CrossRef]

95. Parkin, A.; Man, J.; Timpson, P.; Pajic, M. Targeting the complexity of Src signalling in the tumour microenvironment of pancreatic cancer: From mechanism to therapy. FEBS J. 2019, 286, 3510-3539. [CrossRef]

96. Eliceiri, B.P.; Puente, X.S.; Hood, J.D.; Stupack, D.G.; Schlaepfer, D.D.; Huang, X.Z.; Sheppard, D.; Cheresh, D.A. Src-mediated coupling of focal adhesion kinase to integrin alpha(v)beta5 in vascular endothelial growth factor signaling. J. Cell Biol. 2002, 157, 149-160. [CrossRef] [PubMed]

97. Bolós, V. The dual kinase complex FAK-Src as a promising therapeutic target in cancer. OncoTargets Ther. 2010, 3, 83. [CrossRef] [PubMed]

98. Yokoi, K.; Hawke, D.H.; Oborn, C.J.; Jang, J.-Y.; Nishioka, Y.; Fan, M.; Kim, S.W.; Kim, S.-J.; Fidler, I.J. Identification and Validation of Src and Phospho-Src Family Proteins in Circulating Mononuclear Cells as Novel Biomarkers for Pancreatic Cancer1. Transl. Oncol. 2011, 4, 83-91. [CrossRef]

99. Nuche-Berenguer, B.; Ramos-Álvarez, I.; Jensen, R.T. Src kinases play a novel dual role in acute pancreatitis affecting severity but no role in stimulated enzyme secretion. Am. J. Physiol. Liver Physiol. 2016, 310, G1015-G1027. [CrossRef]

100. Morton, J.P.; A Karim, S.; Graham, K.; Timpson, P.; Jamieson, N.; Athineos, D.; Doyle, B.; McKay, C.; Heung, M.; Oien, K.A.; et al. Dasatinib Inhibits the Development of Metastases in a Mouse Model of Pancreatic Ductal Adenocarcinoma. Gastroenterology 2010, 139, 292-303. [CrossRef]

101. Nagaraj, N.S.; Smith, J.J.; Revetta, F.; Washington, M.K.; Merchant, N.B. Targeted inhibition of SRC kinase signaling attenuates pancreatic tumorigenesis. Mol. Cancer Ther. 2010, 9, 2322-2332. [CrossRef] 
102. Jiang, H.; Hegde, S.; Knolhoff, B.L.; Zhu, Y.; Herndon, J.M.; Meyer, M.A.; Nywening, T.M.; Hawkins, W.G.; Shapiro, I.M.; Weaver, D.T.; et al. Targeting focal adhesion kinase renders pancreatic cancers responsive to checkpoint immunotherapy. Nat. Med. 2016, 22, 851-860. [CrossRef] [PubMed]

103. Wahl, D.R.; Venneti, S. Cancer Metabolism. In Imaging and Metabolism; Lewis, J.S., Keshari, K.R., Eds.; Springer International Publishing: Cham, Switzerland, 2018; pp. 129-154.

104. Pietras, K.; Östman, A. Hallmarks of cancer: Interactions with the tumor stroma. Exp. Cell Res. 2010, 316, 1324-1331. [CrossRef] [PubMed]

105. Sugimoto, H.; Mundel, T.M.; Kieran, M.W.; Kalluri, R. Identification of fibroblast heterogeneity in the tumor microenvironment. Cancer Biol. Ther. 2006, 5, 1640-1646. [CrossRef] [PubMed]

106. Kobayashi, H.; Enomoto, A.; Woods, S.; Burt, A.D.; Takahashi, M.; Worthley, D.L. Cancer-associated fibroblasts in gastrointestinal cancer. Nat. Rev. Gastroenterol. Hepatol. 2019, 16, 282-295. [CrossRef]

107. Okumura, T.; Ohuchida, K.; Kibe, S.; Iwamoto, C.; Ando, Y.; Takesue, S.; Nakayama, H.; Abe, T.; Endo, S.; Koikawa, K.; et al. Adipose tissue-derived stromal cells are sources of cancer-associated fibroblasts and enhance tumor progression by dense collagen matrix. Int. J. Cancer 2018, 144, 1401-1413. [CrossRef]

108. Wei, L.; Ye, H.; Li, G.; Lu, Y.; Zhou, Q.; Zheng, S.; Lin, Q.; Liu, Y.; Li, Z.; Chen, R. Cancer-associated fibroblasts promote progression and gemcitabine resistance via the SDF-1/SATB-1 pathway in pancreatic cancer. Cell Death Dis. 2018, 9, 1065. [CrossRef]

109. Costa, A.; Kieffer, Y.; Scholer-Dahirel, A.; Pelon, F.; Bourachot, B.; Cardon, M.; Sirven, P.; Magagna, I.; Fuhrmann, L.; Bernard, C.; et al. Fibroblast Heterogeneity and Immunosuppressive Environment in Human Breast Cancer. Cancer Cell 2018, 33, 463-479.e10. [CrossRef]

110. Sahai, E.; Astsaturov, I.; Cukierman, E.; DeNardo, D.G.; Egeblad, M.; Evans, R.M.; Fearon, D.; Greten, F.R.; Hingorani, S.R.; Hunter, T.; et al. A framework for advancing our understanding of cancer-associated fibroblasts. Nat. Rev. Cancer 2020, 20, 174-186. [CrossRef]

111. Öhlund, D.; Handly-Santana, A.; Biffi, G.; Elyada, E.; Almeida, A.S.; Ponz-Sarvise, M.; Corbo, V.; Oni, T.E.; Hearn, S.A.; Lee, E.J.; et al. Distinct populations of inflammatory fibroblasts and myofibroblasts in pancreatic cancer. J. Exp. Med. 2017, 214, 579-596. [CrossRef]

112. Goulet, C.R.; Champagne, A.; Bernard, G.; Vandal, D.; Chabaud, S.; Pouliot, F.; Bolduc, S. Cancer-associated fibroblasts induce epithelial-mesenchymal transition of bladder cancer cells through paracrine IL-6 signalling. BMC Cancer 2019, 19, 137. [CrossRef] [PubMed]

113. Apte, M.V.; Haber, P.S.; Applegate, T.L.; Norton, I.D.; McCaughan, G.W.; A Korsten, M.; Pirola, R.C.; Wilson, J.; A Al-Mufti, R.; Williamson, R.C.N.; et al. Periacinar stellate shaped cells in rat pancreas: Identification, isolation, and culture. Gut 1998, 43, 128-133. [CrossRef] [PubMed]

114. Bachem, M.G.; Schneider, E.; Groß, H.; Weidenbach, H.; Schmid, R.M.; Menke, A.; Siech, M.; Beger, H.; Grünert, A.; Adler, G. Identification, culture, and characterization of pancreatic stellate cells in rats and humans. Gastroenterology 1998, 115, 421-432. [CrossRef]

115. Apte, M.V.; Pirola, R.C.; Wilson, J. Pancreatic stellate cells: A starring role in normal and diseased pancreas. Front. Physiol. 2012, 3. [CrossRef]

116. Ferdek, P.E.; Jakubowska, M.A. Biology of pancreatic stellate cells-more than just pancreatic cancer. Pflügers Archiv Eur. J. Physiol. 2017, 469, 1039-1050. [CrossRef]

117. Kusiak, A.A.; Szopa, M.D.; Jakubowska, M.A.; Ferdek, P.E. Signaling in the Physiology and Pathophysiology of Pancreatic Stellate Cells - a Brief Review of Recent Advances. Front. Physiol. 2020, 11, 78. [CrossRef]

118. Biffi, G.; Oni, T.E.; Spielman, B.; Hao, Y.; Elyada, E.; Park, Y.; Preall, J.; Tuveson, D.A. IL1-Induced JAK/STAT Signaling Is Antagonized by TGF $\beta$ to Shape CAF Heterogeneity in Pancreatic Ductal Adenocarcinoma. Cancer Discov. 2018, 9, 282-301. [CrossRef]

119. Somerville, T.D.; Biffi, G.; Daßler-Plenker, J.; Hur, S.K.; He, X.-Y.; E Vance, K.; Miyabayashi, K.; Xu, Y.; Maia-Silva, D.; Klingbeil, O.; et al. Squamous trans-differentiation of pancreatic cancer cells promotes stromal inflammation. eLife 2020, 9. [CrossRef]

120. Nizri, E.; Bar-David, S.; Aizic, A.; Sternbach, N.; Lahat, G.; Wolf, I.; Klausner, J. Desmoplasia in Lymph Node Metastasis of Pancreatic Adenocarcinoma Reveals Activation of Cancer-Associated Fibroblasts Pattern and T-helper 2 Immune Cell Infiltration. Pancreas 2019, 48, 367-373. [CrossRef]

121. Sinn, M.; Denkert, C.; Striefler, J.K.; Pelzer, U.; Stieler, J.M.; Bahra, M.; Lohneis, P.; Dörken, B.; Oettle, H.; Riess, H.; et al. $\alpha$-Smooth muscle actin expression and desmoplastic stromal reaction in pancreatic cancer: Results from the CONKO-001 study. Br. J. Cancer 2014, 111, 1917-1923. [CrossRef] 
122. Fujita, H.; Ohuchida, K.; Mizumoto, K.; Nakata, K.; Yu, J.; Kayashima, T.; Cui, L.; Manabe, T.; Ohtsuka, T.; Tanaka, M. $\alpha$-Smooth Muscle Actin Expressing Stroma Promotes an Aggressive Tumor Biology in Pancreatic Ductal Adenocarcinoma. Pancreas 2010, 39, 1254-1262. [CrossRef] [PubMed]

123. Erkan, M.; Michalski, C.W.; Rieder, S.; Reiser-Erkan, C.; Abiatari, I.; Kolb, A.; Giese, N.A.; Esposito, I.; Friess, H.; Kleeff, J. The Activated Stroma Index Is a Novel and Independent Prognostic Marker in Pancreatic Ductal Adenocarcinoma. Clin. Gastroenterol. Hepatol. 2008, 6, 1155-1161. [CrossRef] [PubMed]

124. Ao, Z.; Shah, S.H.; Machlin, L.M.; Parajuli, R.; Miller, P.C.; Rawal, S.; Williams, A.J.; Cote, R.J.; Lippman, M.E.; Datar, R.H.; et al. Identification of Cancer-Associated Fibroblasts in Circulating Blood from Patients with Metastatic Breast Cancer. Cancer Res. 2015, 75, 4681-4687. [CrossRef] [PubMed]

125. Cun, X.; Chen, J.; Li, M.; He, X.; Tang, X.; Guo, R.; Deng, M.; Li, M.; Zhang, Z.; He, Q. Tumor-Associated Fibroblast-Targeted Regulation and Deep Tumor Delivery of Chemotherapeutic Drugs with a Multifunctional Size-Switchable Nanoparticle. ACS Appl. Mater. Interfaces 2019, 11, 39545-39559. [CrossRef]

126. Özdemir, B.C.; Pentcheva-Hoang, T.; Carstens, J.; Zheng, X.; Wu, C.-C.; Simpson, T.R.; Laklai, H.; Sugimoto, H.; Kahlert, C.; Novitskiy, S.V.; et al. Depletion of Carcinoma-Associated Fibroblasts and Fibrosis Induces Immunosuppression and Accelerates Pancreas Cancer with Reduced Survival. Cancer Cell 2015, 28, 831-833. [CrossRef]

127. Rhim, A.D.; Oberstein, P.E.; Thomas, D.H.; Mirek, E.T.; Palermo, C.F.; A Sastra, S.; Dekleva, E.N.; Saunders, T.; Becerra, C.P.; Tattersall, I.W.; et al. Stromal elements act to restrain, rather than support, pancreatic ductal adenocarcinoma. Cancer Cell 2014, 25, 735-747. [CrossRef]

128. Eric, L.; Yeo, C.J.; Lillemoe, K.D.; Biedrzycki, B.; Kobrin, B.; Herman, J.; Sugar, E.; Piantadosi, S.; Cameron, J.L.; Solt, S.; et al. A Lethally Irradiated Allogeneic Granulocyte-Macrophage Colony Stimulating Factor-Secreting Tumor Vaccine for Pancreatic Adenocarcinoma. Ann. Surg. 2011, 253, 328-335. [CrossRef]

129. Foucher, E.D.; Ghigo, C.; Chouaib, S.; Galon, J.; Iovanna, J.; Olive, D. Pancreatic Ductal Adenocarcinoma: A Strong Imbalance of Good and Bad Immunological Cops in the Tumor Microenvironment. Front. Immunol. 2018, 9. [CrossRef]

130. Zak, K.M.; Grudnik, P.; Magiera, K.; Dömling, A.; Dubin, G.; Holak, T.A. Structural Biology of the Immune Checkpoint Receptor PD-1 and Its Ligands PD-L1/PD-L2. Structure 2017, 25, 1163-1174. [CrossRef]

131. Banerjee, S.; Dudeja, V.; Saluja, A. Unconventional T Cells in the Pancreatic Tumor Microenvironment: Thinking Outside the Box. Cancer Discov. 2019, 9, 1164-1166. [CrossRef]

132. Smith-Garvin, J.E.; Koretzky, G.A.; Jordan, M.S. T cell activation. Annu. Rev. Immunol. 2009, 27, 591-619. [CrossRef] [PubMed]

133. Nishimura, H.; Nose, M.; Hiai, H.; Minato, N.; Honjo, T. Development of Lupus-like Autoimmune Diseases by Disruption of the PD-1 Gene Encoding an ITIM Motif-Carrying Immunoreceptor. Immunity 1999, 11, 141-151. [CrossRef]

134. Henriksen, A.; Dyhl-Polk, A.; Chen, I.M.; Nielsen, R.L. Checkpoint inhibitors in pancreatic cancer. Cancer Treat. Rev. 2019, 78, 17-30. [CrossRef] [PubMed]

135. Lianyuan, T.; Xiu, D.; Chunhui, Y.; Zhaolai, M.; Bin, J. The predictive value and role of stromal tumor-infiltrating lymphocytes in pancreatic ductal adenocarcinoma (PDAC). Cancer Biol. Ther. 2018, 19, 296-305. [CrossRef]

136. Yoshida, S.; Ito, Z.; Suka, M.; Bito, T.; Kan, S.; Akasu, T.; Saruta, M.; Okamoto, M.; Kitamura, H.; Fujioka, S.; et al. Clinical Significance of Tumor-Infiltrating T Cells and Programed Death Ligand-1 in Patients with Pancreatic Cancer. Cancer Investig. 2019, 37, 463-477. [CrossRef]

137. Gao, M.; Lin, M.; Moffitt, R.A.; Salazar, M.A.; Park, J.; Vacirca, J.; Huang, C.; Shroyer, K.R.; Choi, M.; Georgakis, G.V.; et al. Direct therapeutic targeting of immune checkpoint PD-1 in pancreatic cancer. Br. J. Cancer 2018, 120, 88-96. [CrossRef]

138. Fan, P.; Zhao, J.; Meng, Z.; Wu, H.; Wang, B.; Wu, H.; Jin, X. Overexpressed histone acetyltransferase 1 regulates cancer immunity by increasing programmed death-ligand 1 expression in pancreatic cancer. J. Exp. Clin. Cancer Res. 2019, 38, 47. [CrossRef]

139. Tang, Z.; Li, C.; Kang, B.; Gao, G.; Li, C.; Zhang, Z. GEPIA: A web server for cancer and normal gene expression profiling and interactive analyses. Nucleic Acids Res. 2017, 45, W98-W102. [CrossRef]

140. Mehla, K.; Tremayne, J.; Grunkemeyer, J.A.; O'Connell, K.A.; Steele, M.M.; Caffrey, T.C.; Zhu, X.; Yu, F.; Singh, P.K.; Schultes, B.C.; et al. Combination of mAb-AR20.5, anti-PD-L1 and PolyICLC inhibits tumor progression and prolongs survival of MUC1.Tg mice challenged with pancreatic tumors. Cancer Immunol. Immunother. 2017, 67, 445-457. [CrossRef] 
141. Poast, J.; Seidel, H.M.; Hendricks, M.D.; Haslam, J.A.; Levy, H.B.; Baron, S. Poly I:CLC Induction of the Interferon System in Mice: An Initial Study of Four Detection Methods. J. Interf. Cytokine Res. 2002, 22, 1035-1040. [CrossRef]

142. Zhang, Q.; Green, M.D.; Lang, X.; Lazarus, J.; Parsels, J.D.; Wei, S.; Parsels, L.A.; Shi, J.; Ramnath, N.; Wahl, D.R.; et al. Inhibition of ATM Increases Interferon Signaling and Sensitizes Pancreatic Cancer to Immune Checkpoint Blockade Therapy. Cancer Res. 2019, 79, 3940-3951. [CrossRef] [PubMed]

143. Vanpouille-Box, C.; Alard, A.; Aryankalayil, M.J.; Sarfraz, Y.; Diamond, J.M.; Schneider, R.; Inghirami, G.; Coleman, C.N.; Formenti, S.C.; DeMaria, S. DNA exonuclease Trex1 regulates radiotherapy-induced tumour immunogenicity. Nat. Commun. 2017, 8, 15618. [CrossRef] [PubMed]

144. Zhu, Y.; Knolhoff, B.L.; Meyer, M.A.; Nywening, T.M.; West, B.L.; Luo, J.; Wang-Gillam, A.; Goedegebuure, S.P.; Linehan, D.C.; DeNardo, D.G. CSF1/CSF1R blockade reprograms tumor-infiltrating macrophages and improves response to T-cell checkpoint immunotherapy in pancreatic cancer models. Cancer Res. 2014, 74, 5057-5069. [CrossRef] [PubMed]

145. Mirlekar, B.; Michaud, D.; Searcy, R.; Greene, K.; Pylayeva-Gupta, Y. IL35 Hinders Endogenous Antitumor T-cell Immunity and Responsiveness to Immunotherapy in Pancreatic Cancer. Cancer Immunol. Res. 2018, 6. [CrossRef]

146. Hundeyin, M.; Kurz, E.; Mishra, A.; Rossi, J.A.K.; Liudahl, S.; Leis, K.R.; Mehrotra, H.; Kim, M.; Torres, L.E.; Ogunsakin, A.; et al. Innate $\alpha \beta$ T Cells Mediate Antitumor Immunity by Orchestrating Immunogenic Macrophage Programming. Cancer Discov. 2019, 9, 1288-1305. [CrossRef]

147. Porter, D.L.; Hwang, W.-T.; Frey, N.V.; Lacey, S.F.; Shaw, P.A.; Loren, A.W.; Bagg, A.; Marcucci, K.T.; Shen, A.; Gonzalez, V.; et al. Chimeric antigen receptor T cells persist and induce sustained remissions in relapsed refractory chronic lymphocytic leukemia. Sci. Transl. Med. 2015, 7, 303ra139. [CrossRef]

148. Ali, A.I.; Oliver, A.J.; Samiei, T.; Chan, J.D.; Kershaw, M.; Slaney, C.Y. Genetic Redirection of T Cells for the Treatment of Pancreatic Cancer. Front. Oncol. 2019, 9, 56. [CrossRef]

149. Akce, M.; Zaidi, M.Y.; Waller, E.K.; El-Rayes, B.F.; Lesinski, G.B. The Potential of CAR T Cell Therapy in Pancreatic Cancer. Front. Immunol. 2018, 9. [CrossRef]

150. Cutmore, L.; Brown, N.; Raj, D.; Chauduri, S.; Wang, P.; Maher, J.; Wang, Y.; Lemoine, N.; Marshall, J. Pancreatic Cancer UK Grand Challenge: Developments and challenges for effective CAR T cell therapy for pancreatic ductal adenocarcinoma. Pancreatology 2020, 20, 394-408. [CrossRef]

151. Tan, Z.; Xu, J.; Zhang, B.; Shi, S.; Yu, X.; Liang, C. Hypoxia: A barricade to conquer the pancreatic cancer. Cell. Mol. Life Sci. 2020, 1-7. [CrossRef]

152. Koong, A.; Mehta, V.K.; Le, Q.T.; A Fisher, G.; Terris, D.J.; Brown, J.; Bastidas, A.J.; Vierra, M. Pancreatic tumors show high levels of hypoxia. Int. J. Radiat. Oncol. 2000, 48, 919-922. [CrossRef]

153. Hammond, E.M.; Asselin, M.-C.; Forster, D.; O'Connor, J.; Senra, J.; Williams, K.J. The Meaning, Measurement and Modification of Hypoxia in the Laboratory and the Clinic. Clin. Oncol. 2014, 26, 277-288. [CrossRef] [PubMed]

154. Vaupel, P. Tumor microenvironmental physiology and its implications for radiation oncology. Semin. Radiat. Oncol. 2004, 14, 198-206. [CrossRef] [PubMed]

155. Erkan, M.; Reiser-Erkan, C.; Michalski, C.W.; Deucker, S.; Sauliunaite, D.; Streit, S.; Esposito, I.; Friess, H.; Kleeff, J. Cancer-Stellate Cell Interactions Perpetuate the Hypoxia-Fibrosis Cycle in Pancreatic Ductal Adenocarcinoma1. Neoplasia 2009, 11, 497-508. [CrossRef]

156. He, X.; Wang, J.; Wei, W.; Shi, M.; Xin, B.; Zhang, T.; Shen, X. Hypoxia regulates ABCG2 activity through the activivation of ERK1/2/HIF-1 $\alpha$ and contributes to chemoresistance in pancreatic cancer cells. Cancer Biol Ther. 2016, 17, 188-198. [CrossRef]

157. Erkan, M.; Kurtoglu, M.; Kleeff, J. The role of hypoxia in pancreatic cancer: A potential therapeutic target? Expert Rev. Gastroenterol. Hepatol. 2015, 10, 301-316. [CrossRef]

158. Łoboda, A.; Jazwa, A.; Grochot-Przeczek, A.; Rutkowski, A.J.; Cisowski, J.; Agarwal, A.; Jozkowicz, A.; Dulak, J. Heme Oxygenase-1 and the Vascular Bed: From Molecular Mechanisms to Therapeutic Opportunities. Antioxid. Redox Signal. 2008, 10, 1767-1812. [CrossRef]

159. Rankin, E.B.; Giaccia, A.J. The role of hypoxia-inducible factors in tumorigenesis. Cell Death Differ. 2008, 15, 678-685. [CrossRef]

160. Diaz, B.; Yuen, A. The impact of hypoxia in pancreatic cancer invasion and metastasis. Hypoxia 2014, 2 , 91-106. [CrossRef] 
161. Wang, H.; Jia, R.; Zhao, T.; Li, X.; Lang, M.; Lan, C.; Wang, H.; Li, Z.; Zhou, B.; Wu, L.; et al. HIF-1 $\alpha$ mediates tumor-nerve interactions through the up-regulation of GM-CSF in pancreatic ductal adenocarcinoma. Cancer Lett. 2019, 453, 10-20. [CrossRef]

162. Abdalla, M.Y.; Ahmad, I.; Rachagani, S.; Banerjee, K.; Thompson, C.; Maurer, H.C.; Olive, K.P.; Bailey, K.L.; Britigan, B.E.; Kumar, S. Enhancing responsiveness of pancreatic cancer cells to gemcitabine treatment under hypoxia by heme oxygenase-1 inhibition. Transl. Res. 2019, 207, 56-69. [CrossRef] [PubMed]

163. Shibaji, T.; Nagao, M.; Ikeda, N.; Kanehiro, H.; Hisanaga, M.; Ko, S.; Fukumoto, A.; Nakajima, Y. Prognostic significance of HIF-1 alpha overexpression in human pancreatic cancer. Anticancer Res. 2004, 23.

164. Sun, H.-C.; Qiu, Z.-J.; Liu, J.; Sun, J.; Jiang, T.; Huang, K.-J.; Yao, M.; Huang, C. Expression of hypoxia-inducible factor-1 alpha and associated proteins in pancreatic ductal adenocarcinoma and their impact on prognosis. Int. J. Oncol. 2007, 30, 1359-1367. [CrossRef] [PubMed]

165. Jeong, W.; Rapisarda, A.; Park, S.R.; Kinders, R.J.; Chen, A.; Melillo, G.; Turkbey, B.; Steinberg, S.M.; Choyke, P.; Doroshow, J.H.; et al. Pilot trial of EZN-2968, an antisense oligonucleotide inhibitor of hypoxia-inducible factor-1 alpha (HIF-1 $\alpha)$, in patients with refractory solid tumors. Cancer Chemother. Pharmacol. 2013, 73, 343-348. [CrossRef]

166. McGinn, O.; Gupta, V.K.; Dauer, P.; Arora, N.; Sharma, N.; Nomura, A.; Dudeja, V.; Saluja, A.; Banerjee, S. Inhibition of hypoxic response decreases stemness and reduces tumorigenic signaling due to impaired assembly of HIF1 transcription complex in pancreatic cancer. Sci. Rep. 2017, 7, 7872. [CrossRef]

167. Zhang, H.; Qian, D.Z.; Tan, Y.S.; Lee, K.; Gao, P.; Ren, Y.R.; Rey, S.; Hammers, H.; Chang, D.; Pili, R.; et al. Digoxin and other cardiac glycosides inhibit HIF-1 $\alpha$ synthesis and block tumor growth. Proc. Natl. Acad. Sci. USA 2008, 105, 19579-19586. [CrossRef]

168. Wolpin, B.M.; Hezel, A.F.; Abrams, T.; Blaszkowsky, L.S.; Meyerhardt, J.A.; Chan, J.A.; Enzinger, P.C.; Allen, B.; Clark, J.W.; Ryan, D.P.; et al. Oral mTOR Inhibitor Everolimus in Patients With Gemcitabine-Refractory Metastatic Pancreatic Cancer. J. Clin. Oncol. 2009, 27, 193-198. [CrossRef]

169. Kordes, S.; Klumpen, H.J.; Weterman, M.J.; Schellens, J.H.M.; Richel, D.J.; Wilmink, J.W. Phase II study of capecitabine and the oral mTOR inhibitor everolimus in patients with advanced pancreatic cancer. Cancer Chemother. Pharmacol. 2015, 75, 1135-1141. [CrossRef]

170. Babiker, H.M.; Riaz, I.B.; Shah, S.R.; Von Hoff, D.D.; Borad, M.J. Hypoxia-activated prodrugs in the treatment of advanced pancreatic adenocarcinoma. Anti-Cancer Drugs 2017, 28, 127-132. [CrossRef]

171. Borad, M.J.; Reddy, S.G.; Bahary, N.; Uronis, H.E.; Sigal, D.; Cohn, A.L.; Schelman, W.R.; Stephenson, J.; Chiorean, E.G.; Rosen, P.J.; et al. Randomized Phase II Trial of Gemcitabine Plus TH-302 Versus Gemcitabine in Patients With Advanced Pancreatic Cancer. J. Clin. Oncol. 2015, 33, 1475-1481. [CrossRef]

172. Geller, L.T.; Barzily-Rokni, M.; Danino, T.; Jonas, O.H.; Shental, N.; Nejman, D.; Gavert, N.; Zwang, Y.; Cooper, Z.A.; Shee, K.; et al. Potential role of intratumor bacteria in mediating tumor resistance to the chemotherapeutic drug gemcitabine. Science 2017, 357, 1156-1160. [CrossRef] [PubMed]

173. Choy, A.T.; Carnevale, I.; Coppola, S.; Meijer, L.L.; Kazemier, G.; Zaura, E.; Deng, D.; Giovannetti, E. The microbiome of pancreatic cancer: From molecular diagnostics to new therapeutic approaches to overcome chemoresistance caused by metabolic inactivation of gemcitabine. Expert Rev. Mol. Diagn. 2018, 18, 1005-1009. [CrossRef] [PubMed]

174. Pushalkar, S.; Hundeyin, M.; Daley, D.; Zambirinis, C.; Kurz, E.; Mishra, A.; Mohan, N.; Aykut, B.; Usyk, M.; Torres, L.E.; et al. The Pancreatic Cancer Microbiome Promotes Oncogenesis by Induction of Innate and Adaptive Immune Suppression. Cancer Discov. 2018, 8, 403-416. [CrossRef] [PubMed]

175. Sethi, V.; Vitiello, G.A.; Saxena, D.; Miller, G.; Dudeja, V. The Role of the Microbiome in Immunologic Development and its Implication For Pancreatic Cancer Immunotherapy. Gastroenterology 2019, 156, 2097-2115.e2. [CrossRef] [PubMed]

176. Pagliari, D.; Saviano, A.; Newton, E.E.; Serricchio, M.L.; Lago, A.A.D.; Gasbarrini, A.; Cianci, R. Gut Microbiota-Immune System Crosstalk and Pancreatic Disorders. Mediat. Inflamm. 2018, 2018, 1-13. [CrossRef] [PubMed]

177. Sanchez, E.M.R.; Zhang, Y.; Zhang, L.; Montiel, M.; Zoltan, M.; Dong, W.; Quesada, P.; Sahin, I.; Chandra, V.; Lucas, A.S.; et al. Tumor Microbiome Diversity and Composition Influence Pancreatic Cancer Outcomes. Cell 2019, 178, 795-806.e12. [CrossRef] 
178. Farrell, J.J.; Zhang, L.; Zhou, H.; Chia, D.; Elashoff, D.; Akin, D.; Paster, B.J.; Joshipura, K.; Wong, D.T.W. Variations of oral microbiota are associated with pancreatic diseases including pancreatic cancer. Gut 2011, 61, 582-588. [CrossRef]

179. Fan, X.; Alekseyenko, A.V.; Wu, J.; Peters, B.; Jacobs, E.J.; Gapstur, S.M.; Purdue, M.P.; Abnet, C.C.; Stolzenberg-Solomon, R.; Miller, G.; et al. Human oral microbiome and prospective risk for pancreatic cancer: A population-based nested case-control study. Gut 2016, 67, 120-127. [CrossRef]

180. Olivares, O.; Mayers, J.R.; Gouirand, V.; Torrence, M.E.; Gicquel, T.; Borge, L.; Lac, S.; Roques, J.; Lavaut, M.-N.; Berthezene, P.; et al. Collagen-derived proline promotes pancreatic ductal adenocarcinoma cell survival under nutrient limited conditions. Nat. Commun. 2017, 8, 16031. [CrossRef]

181. Heiden, M.G.V.; Cantley, L.C.; Thompson, C.B. Understanding the Warburg Effect: The Metabolic Requirements of Cell Proliferation. Science 2009, 324, 1029-1033. [CrossRef]

182. Gu, D.-N.; Jiang, M.; Mei, Z.; Dai, J.-J.; Dai, C.-Y.; Fang, C.; Huang, Q.; Tian, L. microRNA-7 impairs autophagy-derived pools of glucose to suppress pancreatic cancer progression. Cancer Lett. 2017, 400, 69-78. [CrossRef] [PubMed]

183. Biancur, D.E.; Kimmelman, A.C. The plasticity of pancreatic cancer metabolism in tumor progression and therapeutic resistance. Biochim. Biophys. Acta (BBA) Bioenerg. 2018, 1870, 67-75. [CrossRef] [PubMed]

184. Ying, H.; Kimmelman, A.C.; Lyssiotis, C.A.; Hua, S.; Chu, G.C.; Fletcher-Sananikone, E.; Locasale, J.W.; Son, J.; Zhang, H.; Coloff, J.L.; et al. Oncogenic Kras Maintains Pancreatic Tumors through Regulation of Anabolic Glucose Metabolism. Cell 2012, 149, 656-670. [CrossRef] [PubMed]

185. Son, J.; Lyssiotis, C.A.; Ying, H.; Wang, X.; Hua, S.; Ligorio, M.; Perera, R.M.; Ferrone, C.R.; Mullarky, E.; Shyh-Chang, N.; et al. Glutamine supports pancreatic cancer growth through a KRAS-regulated metabolic pathway. Nature 2013, 496, 101-105. [CrossRef]

186. Schofield, H.K.; Zeller, J.; Espinoza, C.; Halbrook, C.J.; Del Vecchio, A.; Magnuson, B.; Fabo, T.; Daylan, A.E.C.; Kovalenko, I.; Lee, H.-J.; et al. Mutant p53R270H drives altered metabolism and increased invasion in pancreatic ductal adenocarcinoma. JCI Insight 2018, 3. [CrossRef]

187. Alistar, A.; Morris, B.B.; Desnoyer, R.; Klepin, H.D.; Hosseinzadeh, K.; Clark, C.; Cameron, A.; Leyendecker, J.; D'Agostino, R.; Topaloğlu, U.; et al. Safety and tolerability of the first-in-class agent CPI-613 in combination with modified FOLFIRINOX in patients with metastatic pancreatic cancer: A single-centre, open-label, dose-escalation, phase 1 trial. Lancet Oncol. 2017, 18, 770-778. [CrossRef]

188. Gonzalez, P.S.; O’Prey, J.; Cardaci, S.; Barthet, V.J.; Sakamaki, J.-I.; Beaumatin, F.; Roseweir, A.; Gay, D.M.; Mackay, G.; Malviya, G.; et al. Mannose impairs tumour growth and enhances chemotherapy. Nature 2018, 563, 719-723. [CrossRef]

189. Sousa, C.M.; Biancur, D.E.; Wang, X.; Halbrook, C.J.; Sherman, M.H.; Zhang, L.; Kremer, D.; Hwang, R.F.; Witkiewicz, A.K.; Ying, H.; et al. Pancreatic stellate cells support tumour metabolism through autophagic alanine secretion. Nature 2016, 536, 479-483. [CrossRef]

190. Yang, S.; Wang, X.; Contino, G.; Liesa, M.; Sahin, E.; Ying, H.; Bause, A.; Li, Y.; Stommel, J.M.; Dell'Antonio, G.; et al. Pancreatic cancers require autophagy for tumor growth. Genes Dev. 2011, 25, 717-729. [CrossRef]

191. Guillaumond, F.; Bidaut, G.; Ouaissi, M.; Servais, S.; Gouirand, V.; Olivares, O.; Lac, S.; Borge, L.; Roques, J.; Gayet, O.; et al. Cholesterol uptake disruption, in association with chemotherapy, is a promising combined metabolic therapy for pancreatic adenocarcinoma. Proc. Natl. Acad. Sci. USA 2015, 112, 2473-2478. [CrossRef]

192. Nadella, S.; Burks, J.; Al-Sabban, A.; Inyang, G.; Wang, J.; Tucker, R.D.; Zamanis, M.E.; Bukowski, W.; Shivapurkar, N.; Smith, J. Dietary fat stimulates pancreatic cancer growth and promotes fibrosis of the tumor microenvironment through the cholecystokinin receptor. Am. J. Physiol. Liver Physiol. 2018, 315, G699-G712. [CrossRef] [PubMed]

193. Okumura, T.; Ohuchida, K.; Sada, M.; Abe, T.; Endo, S.; Koikawa, K.; Iwamoto, C.; Miura, D.; Mizuuchi, Y.; Moriyama, T.; et al. Extra-pancreatic invasion induces lipolytic and fibrotic changes in the adipose microenvironment, with released fatty acids enhancing the invasiveness of pancreatic cancer cells. Oncotarget 2017, 8, 18280-18295. [CrossRef] [PubMed]

194. Auciello, F.R.; Bulusu, V.; Oon, C.; Tait-Mulder, J.; Berry, M.; Bhattacharyya, S.; Tumanov, S.; Allen-Petersen, B.; Link, J.; Kendsersky, N.D.; et al. A Stromal Lysolipid-Autotaxin Signaling Axis Promotes Pancreatic Tumor Progression. Cancer Discov. 2019, 9, 617-627. [CrossRef] [PubMed] 
195. Petrucelli, N.; Daly, M.B.; Feldman, G.L. Hereditary breast and ovarian cancer due to mutations in BRCA1 and BRCA2. Genet. Med. 2010, 12, 245-259. [CrossRef] [PubMed]

196. Yao, X.; Tian, Z. Saturated, Monounsaturated and Polyunsaturated Fatty Acids Intake and Risk of Pancreatic Cancer: Evidence from Observational Studies. PLoS ONE 2015, 10, e0130870. [CrossRef] [PubMed]

197. Gordon-Dseagu, V.L.Z.; Thompson, F.E.; Subar, A.F.; Ruder, E.H.; Thiébaut, A.C.M.; Potischman, N.; Stolzenberg-Solomon, R. A Cohort Study of Adolescent and Midlife Diet and Pancreatic Cancer Risk in the NIH-AARP Diet and Health Study. Am. J. Epidemiol. 2017, 186, 305-317. [CrossRef] [PubMed]

198. Jiao, L.; Chen, L.; White, N.L.; Tinker, L.; Chlebowski, R.T.; Van Horn, L.V.; Richardson, P.; Lane, R.; Sangi-Haghpeykar, H.; El-Serag, H.B. Low-fat Dietary Pattern and Pancreatic Cancer Risk in the Women's Health Initiative Dietary Modification Randomized Controlled Trial. J. Natl. Cancer Inst. 2017, 110, 49-56. [CrossRef]

199. Strouch, M.J.; Ding, Y.; Salabat, M.R.; Melstrom, L.G.; Adrian, K.; Quinn, C.; Pelham, C.; Rao, S.; Adrian, T.E.; Bentrem, D.J.; et al. A high omega-3 fatty acid diet mitigates murine pancreatic precancer development. J. Surg. Res. 2009, 165, 75-81. [CrossRef]

200. McLaughlin, J.; Lucà, M.G.; Jones, M.N.; D’Amato, M.; Dockray, G.J.; Thompson, D.G. Fatty acid chain length determines cholecystokinin secretion and effect on human gastric motility. Gastroenterology 1999, 116, 46-53. [CrossRef]

201. Petersen, O.H.; Tepikin, A. Polarized Calcium Signaling in Exocrine Gland Cells. Annu. Rev. Physiol. 2008, 70, 273-299. [CrossRef]

202. Morisset, J.A.; Webster, P.D. Effects of Fasting and Feeding on Protein Synthesis by the Rat Pancreas. J. Clin. Investig. 1972, 51, 1-8. [CrossRef] [PubMed]

203. Solomon, T.E.; Vanier, M.; Morisset, J. Cell site and time course of DNA synthesis in pancreas after caerulein and secretin. Am. J. Physiol. Liver Physiol. 1983, 245, G99-G105. [CrossRef] [PubMed]

204. Smith, J.P.; Solomon, T.E. Cholecystokinin and pancreatic cancer: The chicken or the egg? Am. J. Physiol. Liver Physiol. 2014, 306, G91-G101. [CrossRef] [PubMed]

205. Smith, J.P.; Yelamarty, R.V.; Kramer, S.T.; Cheung, J.Y. Effects of cholecystokinin on cytosolic calcium in pancreatic duct segments and ductal cells. Am. J. Physiol. Liver Physiol. 1993, 264, G1177-G1183. [CrossRef] [PubMed]

206. Weinberg, D.S.; Ruggeri, B.; Barber, M.T.; Biswas, S.; Miknyocki, S.; Waldman, S.A. Cholecystokinin A and B receptors are differentially expressed in normal pancreas and pancreatic adenocarcinoma. J. Clin. Investig. 1997, 100, 597-603. [CrossRef] [PubMed]

207. Smith, J.P.; Cooper, T.K.; McGovern, C.O.; Gilius, E.L.; Zhong, Q.; Liao, J.; Molinolo, A.A.; Gutkind, J.S.; Matters, G. Cholecystokinin Receptor Antagonist Halts Progression of Pancreatic Cancer Precursor Lesions and Fibrosis in Mice. Pancreas 2014, 43, 1050-1059. [CrossRef]

208. Smith, J.; Wang, S.; Nadella, S.; Jablonski, S.; Weiner, L.M. Cholecystokinin receptor antagonist alters pancreatic cancer microenvironment and increases efficacy of immune checkpoint antibody therapy in mice. Cancer Immunol. Immunother. 2017, 67, 195-207. [CrossRef]

209. Roderick, H.L.; Cook, S.J. Ca2+ signalling checkpoints in cancer: Remodelling Ca2+ for cancer cell proliferation and survival. Nat. Rev. Cancer 2008, 8, 361-375. [CrossRef]

210. Capiod, T.; Shuba, Y.; Skryma, R.; Prevarskaya, N. Calcium signalling and cancer cell growth. Membr. Biogenesis 2007, 45, 405-427. [CrossRef]

211. Shapovalov, G.; Ritaine, A.; Skryma, R.; Prevarskaya, N. Role of TRP ion channels in cancer and tumorigenesis. Semin. Immunopathol. 2016, 38, 357-369. [CrossRef]

212. Chen, S.J.; Hoffman, N.E.; Shanmughapriya, S.; Bao, L.; Keefer, K.; Conrad, K.; Merali, S.; Takahashi, Y.; Abraham, T.; Hirschler-Laszkiewicz, I.; et al. A splice variant of the human ion channel TRPM2 modulates neuroblastoma tumor growth through hypoxia-inducible factor (HIF)-1/2 $\alpha$. J. Biol. Chem. 2014, 289, 36284-36302. [CrossRef] [PubMed]

213. Schaal, C.; Padmanabhan, J.; Chellappan, S. The Role of nAChR and Calcium Signaling in Pancreatic Cancer Initiation and Progression. Cancers 2015, 7, 1447-1471. [CrossRef] [PubMed]

214. Salido, G.M.; Sage, S.; Rosado, J.A. Biochemical and functional properties of the store-operated Ca2+ channels. Cell. Signal. 2009, 21, 457-461. [CrossRef] [PubMed] 
215. Smyth, J.T.; DeHaven, W.I.; Jones, B.F.; Mercer, J.C.; Trebak, M.; Vázquez, G.; Putney, J. Emerging perspectives in store-operated Ca2+ entry: Roles of Orai, Stim and TRP. Biochim. Biophys. Acta (BBA) Bioenerg. 2006, 1763, 1147-1160. [CrossRef]

216. Kondratska, K.; Kondratskyi, A.; Yassine, M.; Lemonnier, L.; Lepage, G.; Morabito, A.; Skryma, R.; Prevarskaya, N. Orai1 and STIM1 mediate SOCE and contribute to apoptotic resistance of pancreatic adenocarcinoma. Biochim. Biophys. Acta (BBA) Bioenerg. 2014, 1843, 2263-2269. [CrossRef]

217. Chen, Y.-F.; Chiu, W.-T.; Chen, Y.-T.; Lin, P.-Y.; Huang, H.-J.; Chou, C.-Y.; Chang, H.-C.; Tang, M.; Shen, M.-R. Calcium store sensor stromal-interaction molecule 1-dependent signaling plays an important role in cervical cancer growth, migration, and angiogenesis. Proc. Natl. Acad. Sci. USA 2011, 108, 15225-15230. [CrossRef]

218. Yang, S.; Zhang, J.J.; Huang, X.-Y. Orai1 and STIM1 Are Critical for Breast Tumor Cell Migration and Metastasis. Cancer Cell 2009, 15, 124-134. [CrossRef]

219. Flourakis, M.; Lehen'Kyi, V.; Beck, B.; Raphael, M.; Vandenberghe, M.; Abeele, F.V.; Roudbaraki, M.; Lepage, G.; Mauroy, B.; Romanin, C.; et al. Orai1 contributes to the establishment of an apoptosis-resistant phenotype in prostate cancer cells. Cell Death Dis. 2010, 1, e75. [CrossRef]

220. Jian, W.; Junling, S.; Kaili, Z.; Jinmeng, H.; Jiuxing, D.; Jianwei, S.; Wang, J.; Shen, J.; Zhao, K.; Hu, J.; et al. STIM1 overexpression in hypoxia microenvironment contributes to pancreatic carcinoma progression. Cancer Biol. Med. 2019, 16, 100-108. [CrossRef]

221. Khan, H.; Mpilla, G.B.; Sexton, R.; Viswanadha, S.; Penmetsa, K.; Aboukameel, A.; Diab, M.; Kamgar, M.; Al-Hallak, M.N.; Szlaczky, M.; et al. Calcium Release-Activated Calcium (CRAC) Channel Inhibition Suppresses Pancreatic Ductal Adenocarcinoma Cell Proliferation and Patient-Derived Tumor Growth. Cancers 2020, 12, 750. [CrossRef]

222. Giannuzzo, A.; Pedersen, S.F.; Novak, I. The P2X7 receptor regulates cell survival, migration and invasion of pancreatic ductal adenocarcinoma cells. Mol. Cancer 2015, 14, 203. [CrossRef] [PubMed]

223. Giannuzzo, A.; Saccomano, M.; Napp, J.; Ellegaard, M.; Alves, F.; Novak, I. Targeting of the P2X7 receptor in pancreatic cancer and stellate cells. Int. J. Cancer 2016, 139, 2540-2552. [CrossRef] [PubMed]

(C) 2020 by the authors. Licensee MDPI, Basel, Switzerland. This article is an open access article distributed under the terms and conditions of the Creative Commons Attribution (CC BY) license (http://creativecommons.org/licenses/by/4.0/). 